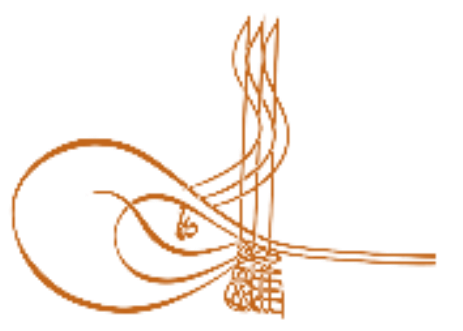

www.turkishstudies.net/turkishstudies
Turkish Studies

eISSN: $1308-2140$

Research Article / Araştırma Makalesi

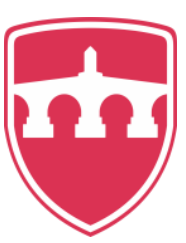

INTERNATIONAL

BALKAN

UNIVERSITY

Sponsored by IBU

\title{
Sanatta Evrimleşen Bakış Açısı: “Anamorfoz” ve Çağdaş Bir Uygulayıcısı Olarak Kurt Wenner
}

\author{
The Evolving Perspective in Art: "Anamorphosis" and Kurt Wenner As a Contemporary \\ Anamorphosis Artist
}

\author{
Yunus Kaya*
}

\begin{abstract}
From the point of view determined by artist, the painting that determines the projection of the viewer does not allow to go beyond what is determined and projection of the image, is no different from a camera viewfinder in this aspect. However, anamorphosis can reconstruct the real image from a particular perspective and often using a material, with the optical effect it creates on the plane based on the reversible deformation of an image. Thus, it tries to offer the viewer more than just a visual because of a visual distortion that produces an illusion for the human eye. However, in the history of art, anamorphosis has not been positioned as it deserves, and the analysis of this phenomenon has been insufficiently artistic aspect. It has also been seen that what is written about it is often confusing and often incorrect. This research, in addition to the terminological, ontological and epistemological scrutiny of "Anamorphosis", as well as examining the evolution process of this form of expression with a chronological method, prioritizes deepening and confusion about this issue with previous research. The next section focuses on the similarities and differences between trompe l'oeil and anamorphosis. In the third chapter, two general types of Anamorphosis: Mirror (Catoptric) Anamorphosis and Perspective (Oblique / Stereoscopic) this research is detailed and exemplified. In the last part of this text, which consists of four parts, the subject is explained with visuals while examining Kurt Wenner, known as the inventor of contemporary anamorphosis, and "3D Street Art", which he created by synthesizing his traditional geometry (madonnari) with his own geometry. The evolutionary process of the "Anamorphosis / Anamorphic Perspective", the first examples of which we see in Renaissance, is presented by forming the general framework of the research.
\end{abstract}

Structured Abstract: In today's (a)wry world, the images and applications based on illusion mechanism rapidly expand the movement area, while applications based on anamorphic principles have become more common than ever in art, advertisement, design, science, maths, technology, medicine, sociology, philosophy and other fields throughout history. Most of the things produced today are defined through "false facts" or have meaning; illusion, deceiving is fashionable, nothing reflects reality, almost thing changes size (transition to multi-dimensional illusion); we often meet with holographic and simulative presentations. People quickly get

\footnotetext{
* Arş. Gör., Ankara Hacı Bayram Veli Üniversitesi, Güzel Sanatlar Fakültesi, Resim Bölümü Res. Asst., Ankara Haci Bayram Veli University, Faculty of Fine Arts, Department of Painting ORCID 0000-0002-3668-3320

y_kaya@outlook.com

Cite as/ Atıf: Kaya, Y. (2020). Sanatta evrimleşen bakış açısı: "anamorfoz" ve çağdaş bir uygulayıcısı olarak Kurt Wenner, Turkish Studies, 15(2), 1079-1099. https://dx.doi.org/10.29228/TurkishStudies.42083

Received/Geliş: 09 March/Mart 2020

Accepted/Kabul: 25 April/Nisan 2020

Copyright $\subset$ MDE, Turkey
} 
used to these innovations in their daily lives and admire such deceptions and illusions. "Anamorfoz" responds to the emotional, perception, logic and artistic needs of the people in this context.

From the point of view determined by artist, the painting that determines the projection of the viewer does not allow to go beyond what is determined and projection of the image, is no different from a camera viewfinder in this aspect. However, anamorphosis can reconstruct the real image from a particular perspective and often using a material, with the optical effect it creates on the plane based on the reversible deformation of an image. Thus, it tries to offer the viewer more than just a visual because of a visual distortion that produces an illusion for the human eye. However, in the history of art, anamorphosis has not been positioned as it deserves, and the analysis of this phenomenon has been insufficiently artistic aspect. It has also been seen that what is written about it is often confusing and often incorrect.

Anamorphosis, which contains confidentiality and contradiction in itself, which enables manipulative actions and experimentation with the ability to screen the reality with a simulative image, has the power to have a dominant effect on the perception of the audience. This invites the viewer to a paradoxical parallax with an illusory sense of perception of depth obtained by superimposing multiple images of an image taken from different angles. Cathoptric anamorphosis can be reconstructed on a mirror-convex surface; On the other hand, streaoscopic anamorphosis can only be perceived in three dimensions by looking at a certain point with a camera or a fisheye lens (etc.). In the observation of the visual with the naked eye in both types of anamorphosis, the three-dimensional image is not noticeable except for the complex paint stain. It can be said that visual perception, which has an important role for anamorphic visuals, is formed by the cognitive harmony of the organ of vision, and the gains acquired through the sensory organs are transformed into information in the mind. When evaluated as a perceptual event, contrary to what is known, in order to make sense of an anamorphic image, the education level of the person, the tradition, belief and culture are not functional. If such visuals are used in terms of angle, height, distance and necessary materials determined by the artist, there is no obstacle in achieving the desired result by every healthy person (who does not have visual or mental disability).

The confusion between the anamorphosis and trope l'oeil's presentation as if they were the same in many studies, or the blur between the boundaries caused by its similar features, causes some vague results. Even though the perspective structure is used in both cases to create an image that is just right from a particular point of view, Perspective anamorphosis is viewed correctly from an unusually specific point of view, and often differs from trompe l'oeil in that it is almost unrecognizable. However, in rompe l'oeil, the artist usually tries to present the whole scene in unity, therefore, it is undesirable any distortion or deformation any part of the image in terms of form. When all these studies are examined, it is understood that anamorphosis and trompe l'oeil are technically a manipulation tool and they are from perspective, and they are both misleading and cause fooling the viewer in perception. However, it is clear that both techniques are different procedures with their own specific rules.

This research, in addition to the terminological, ontological and epistemological scrutiny of "Anamorphosis", as well as examining the evolution process of this form of expression with a chronological method, prioritizes deepening and confusion about this issue with previous research. The next section focuses on the similarities and differences between trompe l'oeil and anamorphosis. In the third chapter, two general types of Anamorphosis: Mirror (Catoptric) Anamorphosis and Perspective (Oblique / Stereoscopic) this research is detailed and exemplified. In the last part of this text, which consists of four parts, the subject is explained with visuals while examining Kurt Wenner, known as the inventor of contemporary anamorphosis, and "3D Street Art", which he created by synthesizing his traditional geometry (madonnari) with his own geometry. The evolutionary process of the "Anamorphosis / Anamorphic Perspective", the first examples of which we see in Renaissance, is presented by forming the general framework of the research.

Keywords: Art, Anamorphic perspective, anamorphosis, Kurt Wenner, trompe l'oeil, 3D Street Art

Öz: Sanatçısı tarafindan belirlenen bakış açısıyla, izleyicinin projeksiyonunu belirleyen ve sunulanın ötesine geçilmesine izin vermeyen resim, bu yönüyle bir fotoğraf makinesi vizöründen farklı değildir. Ancak anamorfoz, bir görüntünün tersinir deformasyonuna dayanarak düzlem üzerinde meydana getirdiği optik etkiyle gerçek görüntüyü yalnızca belirli bir bakış açısıyla ve çoğu zaman da bir materyal kullanılarak yeniden yapılandırabilen, böylece, insan gözü için bir yanılsama üreten görsel bir bozulma olması nedeniyle izleyiciye bir görselden daha fazlasını sunmaya çalışır. Buna rağmen, sanat tarihinde anamorfoz hakkettiği yere

Turkish Studies, 15(2) 
konumlandırılmamış ve bu fenomenin analizi sanatsal bakımdan yetersiz kalmıştır. Ayrıca, hakkında yazılanların da genellikle kafa karıştırıcı ve çoğu zaman da doğru olmadığı görülür. Bu araştırma, "Anamorfoz"un terminolojik, ontolojik, epistemolojik irdelemeleri yanı sıra, sanat tarihi sürecinde bu ifade biçiminin evrimleşmesini kronolojik bir yöntemle derinlemesine incelerken, bu konuda, daha önce yapılan araştırma ve uygulama örnekleriyle derinleşmeyi ve hakkındaki kafa karışıklığını gidermeyi önceler. Sonraki bölümde trompe l'oeil ile anamorfoz arasındaki ilişki: benzerlikler ve farklılıklar üzerinde durulur. Üçüncü bölümde Anamorfozun iki genel türü: Ayna(11) (Catoptric / Katoptrik) Anamorfoz ve Perspektif (Oblique / Eğik / Stereoskopik) Anamorfoz hakkında araştırma detaylandırıl ve örneklendirilir. Dört bölümden oluşan bu metnin son bölümünde ise, çağdaş anamorfozun mucidi olarak bilinen Kurt Wenner ve kendi geometrisiyle Roma geleneksel sokak uygulamalarını (madonnari) sentezleyerek meydana getirdiği "3D Street Art" hakkında öz bir incelemede bulunulur, konu görsellerle açıklanır. Bu derinlemesine yaklaşımla ilk örneklerine L. Davinci’nin resimlerinde karşılaşılan “Anamorfoz / Anamorfik Perspektif”in günümüze kadarki evrimleşme süreci araştırmanın genel çerçevesi oluşturularak sunulur.

Anahtar Kelimeler: Resim, Anamorfik Perspektif, Anamorfoz, Kurt Wenner, Trompe L'oeil, 3B Kaldırım Uygulamaları

\section{Giriş}

İşaretlerin, sembollerin veya kelimelerin düşünceleri harekete geçirme noktasında birer etken olduklarının farkına varılmalıdır, ki bunlar, asla benzedikleri şeyleri anlatmazlar, genelde kastettikleri şeylere de benzemezler ve göründükleri gibi davranmazlar.

Özünde iki boyutlu (2B) bir yapıya sahip olan kâğıt, tuval, fotoğraf, yer (zemin) ya da duvar gibi yüzeyler üzerine yapılmış resimler için "üç boyutlu" (3B) ibaresinin kullanılması çelişkili bir durum gibi görülebilir. Zira bir cismin üç boyutlu olabilmesi için eni ve boyu dışında bir derinliğe de sahip olması gerektiği bilinen bir gerçektir. Gerçeğe birtakım eklemeler veya çıkarmalar yapılması sonucunda gerçekleştirilen ve bilginin işlenmesi esnasında algıda ve düşüncede arzu edilen şeylerin görselleştirilmesi tüm duyu organları ve başka disiplinlerin örgütlenmesiyle çeşitlendirilebilen paralaks imgeler üretilebilir. Özellikle üç boyutlu görsel algı üzerine araştırmalar yapan Zygmunt Pizlo'a göre, insan görsel sistemi üç boyutlu şekilleri algılamak için retinal 2B görüntülere dayandığ1 için, retinalar tarafından algılanan görüntülerdeki bilgiler ile gerçek dünya kaynakları arasındaki ilişkiler şekil belirsizliğine neden olur (2008: 21-27). Meydana gelen bu belirsizlikler iki boyutlu bir görüntünün üç boyutlu görünmesine neden olur. Ancak, bu tür yüzeylerin gerçekte iki boyutlu oldukları unutulmamalıdır. Bu tür paradoksal görseller için Eaton (2011: 5), Anamorfik görüntülerdeki üç boyutla kast edilen şeyin algısal bir olay olduğu ve bunun üzerine ancak görsel bir izlenim geliştirilebileceğine dikkat çeker.

Bu araştırmada kullanılan "üç boyutlu" ifadesi iki boyutlu olduğu halde kullanılan teknik ve gereçlerle üç boyutlu gibi davranan optik ve psikolojik yanılsamaya işaret eder: kütlesi, ağırlığı ve hacmi olan bir nesneye referans vermenin ötesinde, algısal, sanal veya holografik denebilecek bir tür yanılsama şeklinde düşünülmelidir.

Anamorfik görseller için önemli bir role sahip olan görsel algı, görme organı duyumlarının bilişsel harmonisi ile, duyu organları aracılığıyla edinilen kazanımların zihinde bilgiye dönüşmesi sonucunda oluştuğu söylenebilir. Böylelikle alınan duyumlar ve izlenimler bir örgütlenmeye ve bir olguya dönüşür. Algısal bir olay şeklinde değerlendirildiğinde, bilinenin aksine, anamorfik bir görüntüyü anlamlandırabilmek için kişinin eğitim seviyesi, sahip olduğu gelenek, inanç kültür fonksiyonel bir önem taşımaz. Bu tür görsellerin, sanatçı tarafından belirlenen açı, yükseklik, mesafe ve gerekli materyaller kullanılması durumunda, sağlıklı (görme, zihinsel engeli olmayan) her birey tarafından istenen sonuca ulaşılmasında herhangi bir engel yoktur. 
Genel bir tanımlama yapılacak olursa "anamorfoz", çarpık ve çözülemez gibi görünen bir görüntü prosedürüdür aslında; görüntünün sadece eksantrik bir bakış açısı ve uygun bir mercek ile ya da amaca uygun tasarlanmış bir ayna üzerine (veya yansıtma özelliğine sahip bir objeye) yansıtılılmasıyla anlaşılabilir hale geldiği bir ifade biçimini temsil eder. Kurt Wenner'ın ifadesiyle “(...) kendine özgü matematiksel kuralları olan bir "sanatsal dil"dir, nasıl ki Klasizm bir biçim dili ise perspektif de bir boşluk dilidir" (2011: 159, 160), biçiminde nitelendirirken, özellikle de konvansiyonel anamorfoz üzerine derinlemesine tartıșmalar yapan Jurgis Baltrušaitis (1995: 7), “(...)tuhaf bir bakış açısıyla durarak görüntünün yeniden inşası” olarak niteler bu çarpık prosedürü. J. A. S. Colchero (2018: 255) ise bunu, resimde korkunç bir projeksiyon: Deforme olmuş bir düzlem veya kavisli yüzey üzerinde bir görüntünün temsili; belirli bir mesafede düzenli ve orantılı olarak görünen şey olarak anlatır.

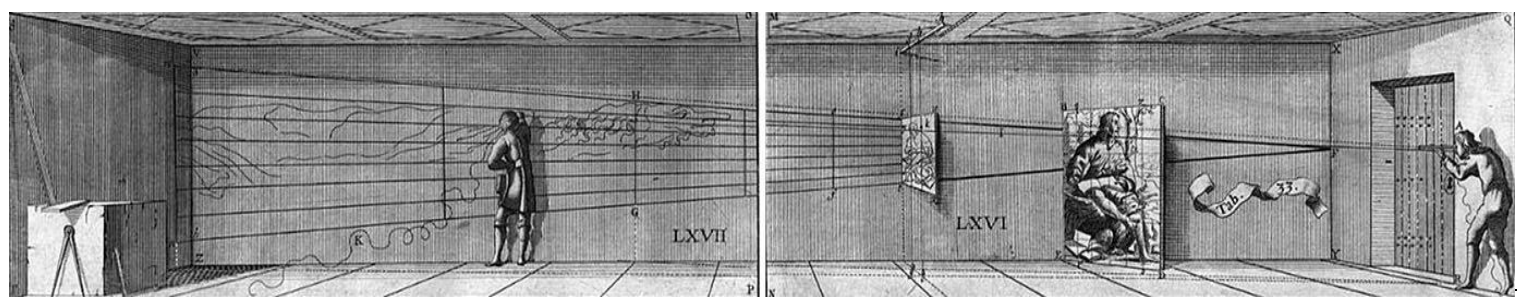

Görsel 1. Jean François Niceron, LXVII ve LXVI, Ters perspektif ve oda rekonstrüksiyon şeması, büyük boyutlu anamorfik görüntüler çizmek için prosedür metodolojileri (Paola, vd., 2015: 255)

Ayrıca Baltrušaitis'in (1977: 1) bu konuyu etraflıca incelediği Anamorphic Art kitabındaki şu değerlendirmesi anamorfozun kapsadığı alanın genişliği ve öneminin anlaşılması bakımından ipuçları verir:

Bu sistem teknik bir merak üzerine ortaya çıkmışsa da, kendi içinde soyut bir şiiri, optik illüzyon üretmek için kullanılacak etkili bir mekanizmayı ve sahte gerçekliğin felsefesini barındırır. Bu bir gizem, bir şaheser, bir mucizedir. İnsanların zihninde her zaman ayıı bir yeri, kendine has bir alanı olan tuhaflıkların dünyasına ait olsa da ara sıra içinde bulunduğu bu dünyanın büyülü atmosferinin ötesine geçer. Bu, tanım olarak, 'bilimsel oyunlar' aslında olduğu sanılan şeyden fazlasıdır (aktaran: Kocalan, Türkdoğan, 2018: 529).

Terminolojik bakımdan incelendiğinde, İngilizceye "Anamorphosis / anamorphic" olarak geçen bu kelime, Türk Dil Kurumu tarafindan henüz buna karşılık gelen herhangi bir sözcük tayin edilmemiş olsa da, sanatçılar ve sanat tarihçileri tarafından "Anamorfik/ Anamorfoz" terimi; çarpıklık, biçimsizlik, bozuk form, deforme edilmiş (resim) gibi anlamlarda yaygın kullanıldığı görülür. Örneğin Sözen ve Tanyeli anamorfozu şu şekilde tanımlar:

İlk örnekleri Leonardo Da Vinci'nin notlarında görülen, ancak belirli bir açıdan ve ayna yardımıyla bakıldığında normal, gerçek oranlarda görülebilen, Avrupa resim sanatında var olan uygulama türüdür. Bu uygulama türü normal biçimde seyredilirse, yalnızca, deforme edilmiş, bozuk biçimli bir resim olarak görülür (2010: 27).

Antik Yunan kökenli anamorfoz kelimesi, geri dönüş anlamına gelen "ana" öneki ve form anlamına gelen "morphosis" soneki ile oluşturulur. Kelimenin etimolojisi, dönüştürülmüş orijinal bir görüntü bulma yeteneğini ifade etse de (Lambert, 2014: 63; Hansford ve Collins, 2007: 211), Yunancadaki öneklerin çeşitli anlamalarda kullanılması anamorfoz kavramının da çeşitli şekillerde yorumlanmasının önemli bir nedeni olarak görülebilir. Bir başka nedeni ise teknik bakımdan deneyselliğe açık olması, gizemli bir yanının olması ve başka disiplinlerle uyumlu bir biçimde işlev görmesinden kaynaklandığı düşünülmektedir. 


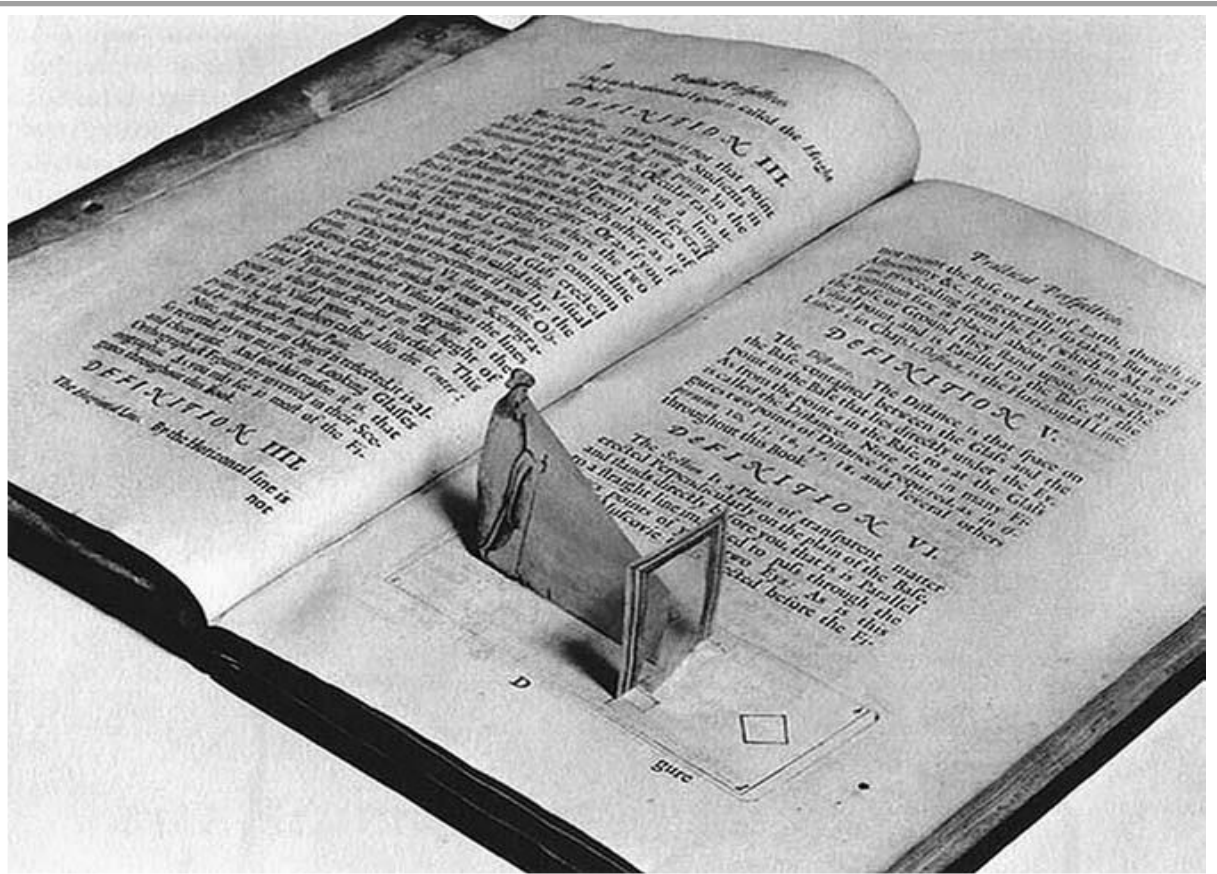

Görsel 2. Joseph Moxon, "Pop-up” perspektif gösterisi, 1670, Smithsonian Enstitüsü Kütüphanelerinin izniyle, Washington, DC, (Boyle, 2010: 10)

$\mathrm{Bu}$ prosedür, gerçek bir mekânı ya da nesneyi simüle etmek için bilinçli bir şekilde kurgulanmış bir yanılsama biçiminde ibaret olsa da manipüle edilmiş mekân, nesne ya da görsel yalnızca belirli görüntüleme koşulları altında doğal formlarında görünmesine olanak sağlayan bir tasarım yöntemidir aynı zamanda. Bir manipülasyon aracına olarak da görebileceğimiz bu prosedürü Lazzaro ve Murra şu cümle ile özetler: "Anamorfik teknikler, perspektif yanılsamasının keyfini çıkarmanın dışında, önemli (gizli) bilgileri gizlemek için kullanılmıştır” (2014: 145). Bir bilgiyi, olayı, düşünceyi, görseli ya da metni şifreleme yöntemi olarak da kullanılan anamorfoz, Murra and Lazzaro'nın ifadediyle: "Bir mektupta, bir cümle veya bir çizim anamorfoz tarafindan kamufle edilebilir". Ancak kâğıda dikey olarak yerleştirilmiş uygun bir ayna ile yansımasına bakıldığında okunabilir hale gelir, böylece mektubun gerçek içeriği anlaşılabilir (2013b: 47, 48). Buradan da anamorfozun genel olarak bir gerçeği manipüle etme konusunda kriptotik bir teknik özelliğe sahip olduğu anlaşılabilir: özellikle de konik aynalarla yapıldığında deşifre edilmesi çok daha zor olduğu da söylenebilir.

$\mathrm{Bu}$ tür bir yöntemle elde edilen görseller konvansiyonel perspektif argümanlarıla izlendiğinde tezat oluşturacağı için izleyicide kafa karışıklığına neden olur. Çünkü uygulamada doğrusal perspektifin tersi işler ve bilindik tüm kurallar tersten uygulanın çoğunlukla, böylesi bir görselin okunması da bu nedenle zorlaşır. Caffio (2018: 1295) bunu, "Bazı açılardan anamorfoz genel bakış kurallarını reddederek, rahatsızlık veren bir dizi çarpıtmalar(...)" şeklinde yorumlar.

$\mathrm{Bu}$ araştırma temelde fizik, matematik, optik, fizyoloji, psikoloji, sosyoloji, din, çizim, sanat ve tarihin bir araya geldiği ve bunların her biriyle bir şekilde ilintili olduğu kadar her birinden önemli ölçüde beslenen "Anamorfoz"u araştırır. Bu alanların her biri farklı, kendine özgü prensiplerle anamorfoz konusuna yaklaşırken, bu tip yanılsamaların ve projeksiyonların yeniden yapılandırılması ve yorumlanmasıyla güncel sanatta etkin bir biçimde karşılık bulur.

$\mathrm{Bu}$ araştırma kapsamında, anamorfoz kavramının anlamı, kökeni, sanat tarihindeki yeri, günümüz sanatındaki konumu ve bu konudaki karışıklığın giderilmesi için kapsamlı bir araştırma, literatür taraması, görsel incelemeler ve kişisel iletişim yöntemleriyle veriler elde edilme yöntemiyle sunulur. Bu kapsamda, "Anamorfoz"un kökeni, kronolojik bakımdan incelerken, bu konuda, daha 
önce yapılan araştırma ve uygulama örnekleriyle derinleşmeyi ve hakkındaki kafa karışıklığını gidermeyi amaçlamakla birlikte, çağdaş anamorfozun mucidi olarak bilinen Kurt Wenner ve "3D Street Art" konusunun araştırmayı da önemser.

\section{Anamorfoz Tarihi}

Dürer, Giotto ve Massacio gibi ustalar iki boyutlu yüzey üzerinde üçüncü boyut elde etmek için yaptıkları araştırma ve uygulamalar şüphesiz önemlidir. Ne var ki, Brunelleschi, düz yüzey üzerine yapılmış resimlerin üç boyutlu gibi görünmesini sağlayan tekniğin mucidi olduğunu iddia ediyordu (Stillwell, 2010: 128), ama icadın patentini başka bir Floransalı Leon Battista Alberti kapacaktı: 1434 tarihli Della Pittura/Resim Üzerine adlı yazısıyla. Dönem atmosferinde önemli bir etkiye sahip olan bu kısa metin, perspektife dayalı uzamın nasıl kurgulanacağını tarif ediyordu. Alberti'nin fikrinin ardından, Fransız matematikçi Desargues geometrik modelinde sonsuzluğa bir nokta ekledi (Dahan-Dalmedico ve Pfeiffer 1984: 130'den aktaran: Lambert, 2014: 64). Böylece hem görsel sanatlar hem de matematik içinde, aynı anda birden fazla noktanın kullanılabileceği fark edildi; bu nedenle sonsuzluk için iki ve üç noktadan oluşan farklı perspektif modelleri ortaya çıktı (Coxeter 1974: 3'den aktaran: Lambert, 2014: 64). O günden bu yana perspektif her yönüyle ve her açıdan tartışılan bir mesele haline geldi. Fakat tartışmalar, en çok yeni soruların gündeme geldiği 20. yüzyılda etkisini gösterdi: Perspektifi icat eden gerçekten Brunelleschi miydi, yoksa Romalılar mı? Tam da bu nokta da Hans Belting, yıllar sonra, bu tartışmaya Floransa ve Bağdat kitabındaki bilimsel açıklamalarıyla bilinenleri tersyüz edecek bir iddiayla katılıyor: Resimlerde uzamı tasvir etmek için kullanılan bu çarpıcı yöntemin ana esin kaynağının, 11. yüzyılda yaşamış Arap matematikçi İbnü'lHeysem'in (Latince adıyla Alhazen) (965-1040) optik üzerine araştırmaları ve kuramları olduğunu söyler (Belting, 2017: 34).

Sanat dışında bilinen en eski anamorfoz örneği (Accolti, 1625'den aktaran: Lazzaro, vd., 2019: 360) mimar ve matematikçi Accolti'nin Floransa'daki Carlo de 'Medici kitabında bulunabilir. $\mathrm{Bu}$ kitap, gizli yazıları ve haritaları şifrelemek / gizlemek için kullanılan anamorfik çizimlerden bahseder (Lazzaro, vd., 2019: 360). Optik veya perspektifin kim tarafindan nerede, ne zaman, nas1 keşfedildiği tartışmaları bir yana dursun; perspektifin bir alt dalı olan anamorfik perspektifin on beşinci yüz yılda sanat dünyasına girdiği konusunda genel genel bir konsensüs olduğu görülür. Örneğin K.H. Veltman, anamorfik resimlerin doğrusal perspektifin geliştirilmesinden kısa bir süre sonra İtalyan sanatında ve mimarisinde ortaya çıktığını belirtirken (1986: 101; Wade ve Hughes: 1999: 1116), daha kapsamlı bir açıklama Cabezos ve arkadaşlarının ifadelerinde görülebilir: İspanyol Kraliyet Akademisinin, "Bakış açısına bağlı olarak çarpık ve kafa karıştırıcı bir görüntüye sahip resim, çizim veya görünüm" şeklinde tanımladığı, geleneksel bir ifadeyle, gözlemciye göre eğik bir yüzeye yerleştirilen çizimler olan anamorfoz, İtalya'da Barok'un görkemli anlayışından doğan ve quadraturizm olarak adlandırılan, sahte mimarileri temsil etmeye yarayan; perspektifi mimari yüzeylere aktarmak için kullanılan referans 1zgaraya atıfta bulunan "quadratura" teriminden türetilmiştir (Cabezos vd., 2014: 149). Wenner (2011: 160) ise, daha genel bir değerlendirmeyle bunu klasik perspektif temellerine ve İtalyan chiaroscuro'suna (1şık-gölge oyunu) dayandırır. İlk bakışta araştırmacıların açıklamaları kafa karıştırıcı ve farklı ontolojik yaklaşımlar sergilediği düşünülse de aslında, burada Wenner'ın Cabezos vd. ile ters düşen bir ifadesi olmadığı, sadece teknik bakımdan farklı noktaya ya da bir detaya dikkat çekmeye çalıştığı anlaşılabilir. 


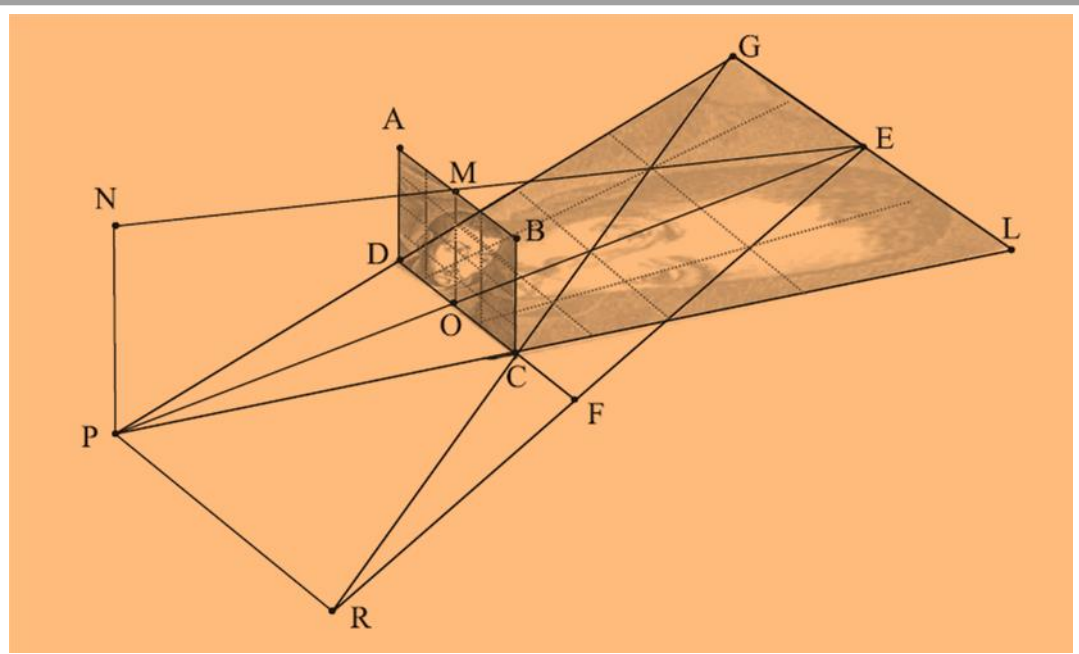

Görsel 3. Jean François Niceron'un anamorfik perspektifle oluşturulan portresinin üç boyutlu görünümü (Lazzaro, 2019: 359)

1500 'lerin sonu ile 1700 'ler arasında, gerçek bir manzara izlenimi veren resimler oluşturmak için perspektif üzerinde bir dizi gelișmeler yașandı. Bunlardan bazıları anamorfoz ile ilgiliydi. Bu tekniğin varlığını ve on 16. yüzyılda kullanımının yükselişini kanıtlayan ilk yazarların Vignola ve Barbaro olmuştur (García, 2016: 30; Cabezos vd., 2014: 149). Özellikle Vignola, anamorfozda, resimsel düzlem ile göz arasındaki mesafenin teknik kontrolüne sahip olmasının önemine dikkat çekiyordu (García-Salgado, 2001: 11). Ancak ilk kez 1630'da Vaulezard silindirik ve konik anamorfozu gerçekleştirmek için geometrik yöntemleri tanımlayan araştırmalar yaptı (CabezasJiménez, 2007: 171). Daniele Barbaro'un (1568) perspektifin güzel ve gizli bir kısmı'nın sergilediği çalışmaları, Vignola'nın (1583) (sonradan yayınlanan) İki Pratik Perspektif Kuralı ve Resim Sanatına İlişkin Inceleme yazısı, Schön tarafından 1535 tarihli anamorfik gravürleri, Giovanni Paolo Lomazzo (1585) tarafından yapılan heykeller ve daha sonra sorunu çok daha derinlikli ve titizlikle ele alan Jean François Nicéron'un (1638) La perspektif curieuse, ou magie artificielle... bu alanda dönemlerinin konu üzerinde yapılan önemli araştırma ve uygulamalarıdır. Nicéron tam olarak anamorfozun ne olduğunu bu yazısıyla açıklıyordu (Edgerton, 1979: 133; Cabezos vd., 2014:150; Lazzaro ve Murra, 2013a: 9, 10). Fransa ve İtalya'daki Fermat, Descartes, Cavalieri ve Kircher gibi önde gelen bilim adamları ile tanışan Nicéron perspektif üzerine son teorik gelişmelerin farkındaydı. Perspektifin sunduğu sorunlara bilimsel bir çözüm arayışına giren Nicéron, anamorfik sanat üretmek için geometrik algoritmalar üzerinde çalışmalarının bir sonucu olarak ortaya çıkıyordu bu metin (shorturl.at/kpwAT). Elbette, García Hidalgo (1681), Pozzo (1693), Galli'in (1711) ve Palomino (1724) gibi diğer araştırmacıların da anamorfoza yönelik çabaları göz ardı edilemez. Fakat Cizvit Babası Andrea Pozzo'nun incelemeleri kesinlikle Barok'un en önemli uygulamalarından biriydi. En önemli eserlerinden biri, Saint Ignatius'un zaferini konu alan sahte kubbeyi öne çıkaran Roma'daki Saint Ignatius Kilisesi'ndeki tavan resimleridir (Cabezos vd., 2014: 150).

Prosedürün kendisi, Piero della Francesca'nın (1415-1492) 1472'deki perspektif konusundaki çalışmaları sayesinde bilindiği (Colchero, 2018: 255; Paola, Pedone, Inzerillo, ve Santagati, 2015: 254) iddiaları yanı sira, anamorfozu tam olarak tanımlayan ilk belge Leonardo da Vinci'nin bir çocuğun çarpık yüzünün çizildiği Atlantik Kodeksi ( 1515) olduğu (Seckel, 2004:11; Baltrusaitis, 1977'den aktaran: Collins, 1992: 81; Lazzaro, ve Murra, 2013a: 8) görüşü daha çok kabul görür araştırmacılar tarafından. Kodeks'de Leonardo, bir ışık kaynağının bir yüzeye çizilecek nesnenin gölgesini yansıttığı bir delikten yararlanan bir anamorfoz inşa etme tekniğini gösterir bu uygulamasında (Lazzaro ve Murra, 2013b: 42). Tüm bu araştırma ve uygulamalara rağmen 
Wenner'ın da (2011: 173) belirttiği gibi tüm bu araştırma ve uygulamalar anamorfik perspektif/anamorfozun, 17. yüzyıla kadar sanatsal bir teknik geliştir(e)memiştir.

Barokta bu perspektif türüyle oluşturulan kompozisyonlar çoğunlukla katedrallerin tavan ve kubbelerinin iç kısımlarında, yerden ve izleyiciden oldukça yüksekte tasarlanır ve buraya uygulanır. İzleyici bu kompozisyonlara aşağıdan/ uzaktan eğik bir açıyla bakarak figürleri orantılı olarak görebiliyordu. Bazı noktalarda bu tür tavan resimlerine bakıldığında pencere, içeri giren güneş ışığı, yapı kirişleri, sütun başlıkları gibi bazı mimari elemanlar kompozisyonun içinde harmanlanır ve bir bütünlük içerisinde kompozisyonun devamıymış gibi görüntüler sunar.

16. ve 18. yüzyıllar arasında birçok sanatçının hem teorik hem de pratik olarak bu konuya ilgi duyması ve geometrik kuralların daha iyi anlaşılması nedeniyle, birçok anamorfoz tipinin denendiği saptanabilir. Tekniğe karşı duyulan merak ve ilginin bir sonucu olarak orta ve kuzey Avrupa'ya hızlıca yayılasına katkı sağlar (Leeman, ve Schuyt, 1976'den aktaran: Spiliotis, 2008: 23).

Ayna anamorfozu olarak da isimlendirilen bu tip uygulamalar (ilerleyen bölümlerde ayrı bir başlık altında detaylandırılmıştır) Seckel'e (2004: 11-42) göre, izleyicisini şaşırtmakla birlikte, çoğunlukla siyasi, kiliseye aykırı ya da toplum geleneklerine uygun düşmediği düşünülen, sanatçının gizlemek istediği mesajlar içeriyordu. Çıplak gözle bakıldığında kolaylıkla anlaşılamayan bu tür resimler böylesi mesajlar için idealdi.

18. yüzyıl perspektifçilerinin bu tekniğe karşı ilgisizliği veya merak eksikliğinin bir başlangıç aşamasıdır. Meraklı (gizli/anamorfik) perspektif olgusunu titizlikle araştırıldığı kanaatiyle, bu alandaki çabalarını reddediyor ve anamorfoz kullanımını sadece optik bir sapmaya indirgenmesi gerektiğini düşünüyorlardı. 19. yüzyılın sonlarında fotoğrafçılığın gelişmesiyle birlikte, Le Transformisme En Photographie Par Le Pouvoir De Deux Fentes/İki Yartk Gücüyle Fotoğrafta Dönüşüm 'ün yazarı Louis Ducos du Hauron'un otoportresi gibi farklı anamorfik deformasyon uygulamaları gerçekleştirildi (Cabezas-Jiménez, 2007: 182, 185).

19. yüzyılın son çeyreğinden 20. yüzyılın son çeyreğine yakın bireysel ve nadir uygulamalar haricinde çok fazla tercih edilmemiş, hatta modernistler tarafından çoğunlukla salt yanılmama ve eğlendirme amacı taşıdığ 1 düşüncesiyle özellikle perspektif anamorfoz türünden uzak duruldu. 1960'lardan sonra çeşitli nedenlere bağlı olarak yeniden önem kazanmaya başlayan bu tekniğin iyi bir örneği Salvador Dali'inn Mathew, uygulamasında görülebilir (Bkz. Görsel 4).

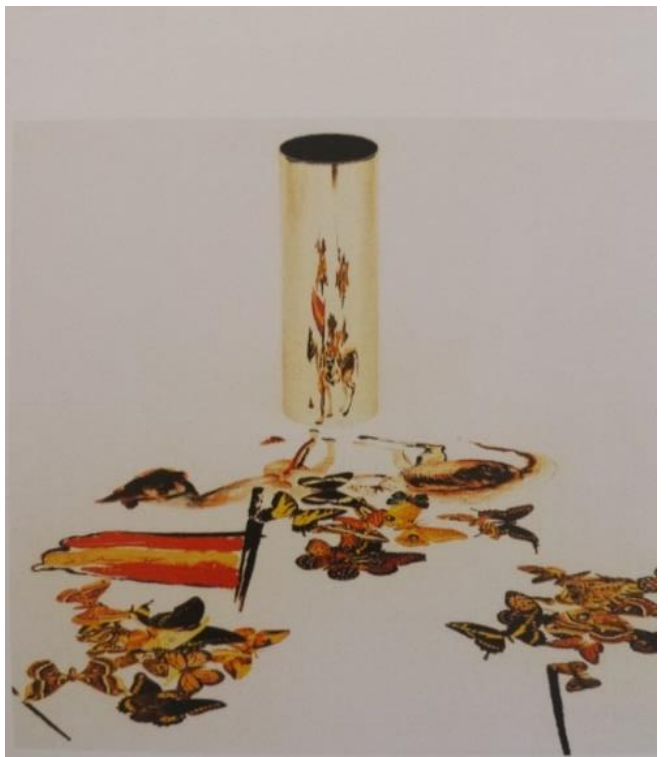

Görsel 4. Salvador Dali, Mathew, 1974, 88 x 64 cm, Silindir üzerine yansitılmış, (Seckel, 2004: 42) 
Zamanla, uygulama alanını genişleterek izleyiciye panoramik izlenimler sunmaya başlayan anamorfoz, izleyicinin 360 derecelik bir sahnenin parçası olmaya yanıltıldığı silindirik binaların iç duvarlarına uygulanması, kendisine olan ilginin daha da artmasının nedenleri arasında gösterilebilir. Bunun ilk örneği 1792 'de Robert Barker tarafindan yapıldı ve 19. yüzyılda dünya şehirlerinde panoramaları barındıran yüzlerce bina inşa edildi. Ayrıca, özel efektlerin gelmesinden önce tiyatro ve film sahnelerinde kullanıldı. Salvador Dali ve Oscar Tusquets arasındaki iş birliğinin sonucu olarak, 1975 yılında yapılan Figueras'daki Dali Müzesi'nin Mae West Odası'nda S. Dali tarafindan boyanmış Mae West portresinin mekânsal bir yorumunu sunan dönemin önemli örneklerinden biridir (Cabezos vd., 2014: 154). Günümüze doğru gelindiğinde, çalışmalarını anamorfoz kullanarak karakterize eden bir başka sanatçı Felice Varini'dir (1952-). Sanatçı gerçek bir mekânda bir dizi basit geometrik şekillerle çizgisel bir devamlılık sunan özgün bir konsepte sahip bu alanın önemli isimlerinden biri olarak gösterilebilir.

1960 ve 1970'lerde İsveçli sanatçı Hans Hamngren'nın yaptığı ayna yansımalı çalışmaları, 1970 ve 1980'lerde Japon sanatçı Shigeo Fukuda (1932-2009) hem perspektif hem de ayna yansımalı çalışmalar yaptı. Ayrıca Patrick Hughes, Fujio Watanabe, William Kentridge, Jonty Hurwitz, István Orosz, Felice Varini, Matthew Ngui, Kelly Houle, Nigel Williams ve Judy Grace anamorfik görüntüler yaratan önemli sanatçıların yanı sıra M. C. Escher (1898-1972) ve Rob Gonsalves'nın (1959-2017) bu alanda kendilerine özgü uygulamalarıyla bilinir. Kendine özgü manipülatif bir dil oluşturularak sokakları boyayan ve çağdaş anamorfozu geliştirdiği kabul edilen Kurt Wenner, kullandığı farklı malzeme, yöntem ve değişik tarzdaki uygulamalarıyla; E. Müller, T. L. Stum, F. Abelanet, J. Beever, Manfred Stader, Eduardo Relero gibi birçok sanatçının bu alana ilgi duymasına yol açar. Böylece anamorfik imgeler günümüzde yeniden ve hızlı bir biçimde canlılık kazanır ve çağdaş sanatçılar tarafindan ilgi odağı haline gelir. İzleyici, nesne, mekân ve plastik unsurlar arasındaki ilişki yeniden sorgulatan F. Guilloud, Georges Rousse, Fanette Guilloud, Bernard Pras, Sue Webster ve Tim Noble gibi sanatçılar da anamorfozu etkin bir şekilde kullanan sanançılardır. Ayrıca yeraltı sanatında, sosyal eleştiriyle ilgili grafiti anamorfozun minimalist bir versiyonunu kullanan esrarengiz sanatçı Banksy tarafından yapılan uygulama örnekleri de bulabiliriz, ancak bu, onları daha az etkileyici yapmaz.

Gelişen bilgisayar ve yazılım teknolojileri, fotoğrafçılık projektif bir dönüşüm gerçekleştirirken anamorfoz yaratmanın alanı daha da genişler. Bunlardan biri ise sanal gerçeklik ve artıılmış gerçekliğe dayalı uygulamalar da aynı prensipleri kullanıldığı görülür. Ayrıca, binalara görüntü yansıtmak için yenilikçi video haritalama tekniklerin de bu tür yöntemlerle oluşturulduğu söylenebilir. Son yıllarda hemen her alanda ihtiyaç duyulan veya kullanılan 3D (3B) yazıcıların geliştirilmesinde de yine kurt Wenner'ın çağdaş anamorfoz için geliştirdiği matematiksel prensiplerin önemi göz ardı edilemez.

\section{Trompe L'oeil ve Anamorfoz İlişkisi}

Çoğu araştırmac1, yine bir tür çarpıtma yoluyla elde edilen "trompe l'oeil”" (göz aldatması) ile "anamorfoz"u aynı şeylermiş gibi değerlendirirken, kimileri ise, daha temkinli yaklaşır bu duruma. Ancak her iki yöntemin birçok ortak noktaları olmakla birlikte, birbirinin aynısı olmadıklarını özellikle belirtmek gerekir. Bu bağlamda Kurt Wenner'ın ifadesi de oldukça açıktır: "Barok dönem tavan resimleri bazen anamorfik perspektifi ve trompe l'oeil'yi bir arada kullanır" (2011: 173). Roma'da ENEA'da (Radyasyon Uygulamalarının Geliştirilmesi Teknik Birimi) anamorfoz üzerine araştırmalar yapan Paolo Di Lazzaro ve Daniele Murra'nın (2013b: 51), "Büyük ölçekli anamorfozların ve trompe l'oeil'lerin çoğu 1500-1700 yılları arasında yapıldı" cümlesi de iki şeyin birbirinden farklı olduklarına işaret eder. Ayrıca trompe'l'oeil, M.Ö. V. yüzyılda yaşamış Zeuxis, adlı ressam ile aynı dönemde yaşayan Efes'li Parrhasius adlı ressam arasındaki çekişme sonucu yapılan yarışmaya kadar köklendirilebilirken, anamorfoz ise erken Rönesans'a kadar götürülebilir. 
İkisinin birbirinden farklı olduklarını değerlendiren, yeterince açık ve kapsamlı bir başka açılama ise Dynamic Anamorphosis As a Special, Computer-Generated User İnterface araştırmasında yer verilir: Perspektif yapısının her iki durumda da sadece belirli bir bakış açısından doğru görülen bir görüntü oluşturmak için kullanılması bakımından perspektif anamorfozu ile trompe l'oeil'ün birbiriyle yakından ilişkilidir. Perspektif anamorfoz genellikle alışılmadık bir bakış açısından doğru bir şekilde görülür ve genellikle neredeyse tanınmayacak kadar çarpıtılmış standart bir bakış açısından görülür. Öte yandan, bir trompe l'oeil resmi standart bir bakış açısından gerçekmiş gibi bir görüntü sunar. En iyi bilinen örnekler, belirli bir bakış açısından düz bir tavanı kubbelerin, kulelerin simülatif izlenimler sunan Barok tavan resimleridir (Ravnik vd., 2014: 47).

Tüm bu araştırmalara bakıldığında anamorfoz ve trompe l'oeil'ün teknik bakımdan birer manipülasyon aracı olduklarını ve perspektif kaynaklı olduklanı, aynı zamanda ikisinindi yanıltıcı ve izleyiciyi algıda kandırmaya neden oldukları anlaşılmaktadır. Ancak her iki tekniğin kendine özgü kuralları olan farklı prosedürler oldukları da açıkça anlaşılmaktadır.

\section{Anamorfoz Çeşitleri}

Anamorfozun temelde iki türü vardır; perspektif (stereoskopik) ve ayna (katotropik) (Melnikova, 2011: 22; Gerhold ve Rose, 2012: 449). Perspektife dayalı olan 15. yüzyıla kadar: Hatta perspektifin yanlış kullanımı sonucu elde edilen bilinçsiz uygulama örnekleri antik döneme kadar götürülebilir. Aynaya dayalı olan ise, 17. yüzyıla kadar bir geçmişe sahip önceki bölümlerde anlatılmıştı.

\subsection{Ayna (Catoptric/Katoptrik) Anamorfozu}

Kendi anlatımları için perspektifin yetersiz kaldığını düşünen kimi sanatçılar başka arayışların içerisine girmesi sonucunda bu tip keşiflerde bulunmuştur. Sanatçının katotropik uygulamalar yapmasındaki temel amaç izleyicisini şaşırtmanın ötesinde, anlatılması ya da gösterilmesi sakıncalı, yasak veya toplumun bir kesimi tarafından hoş karşılanmayan şeyleri manipülatif ve gizli bir biçimde ifade etme aracı olarak ortaya çıktı̆̆ ifadeyle, dönemin sosyal ve kültürel etkileşimi sonucu bir gereksinim olarak ortaya çıkar bu yöntem. Sanatçı bu yöntemle asıl anlatmak istediğini resimde gizleyerek izleyicisine sadece ayna özelliği taşıyan (koni, silindir, prizma vb.) bir cisim ile orijinal (istenen) görüntüye erişimini sağlar.

Aynalı anamorfozda görüntüyü toplayan bir silindir veya koniye ihtiyaç vardır. Yüzey üzerine deforme edilmiş görüntü ayna etrafından toplanır ve böylelikle normalleştirilmiş görüntü elde edilebilir. Ancak oluşturulan çarpıklıktan dolayı görüntünün bazen ayna üzerinde bile tanınması zor olabilir.

Konideki yansımasına bakıldığında baş aşağı çevirmiş "A" harfinin zemin üzerine çizilen çarpık görüntüsü aynanın üstünde bulunan bir gözlemci tarafından aynalı koni üzerinde nasıl algılandığı gösterilmektedir (Bkz. Görsel 5). Gözlemci tarafindan algılanan kesikli çizgiler, gözlemciye konik ayna ve koni tabanına kendi ideal görüntüsünün devamı olarak yansıyan ışınları göstermektedir (Lazzaro ve Murra, 2013a: 17). 


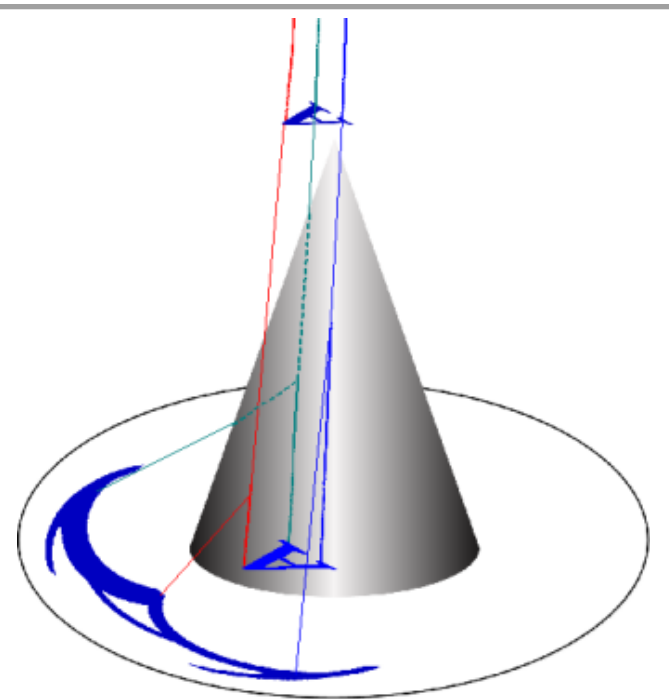

Görsel 5. "A” harfinin koni üzerine anamorfik görüntüsünü gösteren bir örnek, (Lazzaro ve Murra, 2013: 17)

Deforme olmuş görüntü, anamorfozun perspektif sistemi aracılığıyla başka bir bakış açısıyla tanınamayan ideal bir noktanın gözlemlenmesini gerektirdiği için izleyicide kafa karışıklığına, şaşkınlığa bazen de (genellikle çarpıtma algısı çözüldükten sonra) hayal kırıklığına neden olan çeşitli tepkilere yol açar. Master of Deception kitabında kapsamlı bir biçimde yanılsama konuları ele alan Al Seckel ayna anamotfozun izleyici üzerindeki bu tür etkilerden şu şekilde bahseder:

Yapılan çarpık ya da bozuk görünümlü bu tür anamorfik resimler, 17. yüzyıl itibariyle bir koni, silindir, piramidal üçgen ya da ayna yardımıyla, onların gerçek, muhteşem oranlarda görüntüsü elde edilebilen türden imgeler sunar. Bu tür görseller, izleyicinin yaşına, hangi kültüre sahip olduğuna, sanatla ilgilenip ilgilenmediğine bakılmaksızın, onu şaşırtma ve oyun yoluyla eğlendirerek mutlu eder (2004: 11).

Günümüzde daha az yaygın olarak kullanılan bu yöntemin önemli uygulayıcılarından biri Istvan Orosz'dur. Sanatçı, diğer gravürlerinde olduğu gibi Mysterious Island/Esrarengiz Ada'sında da bunun başarılı bir örneğini bizlere sunar (Bkz. Görsel 6).

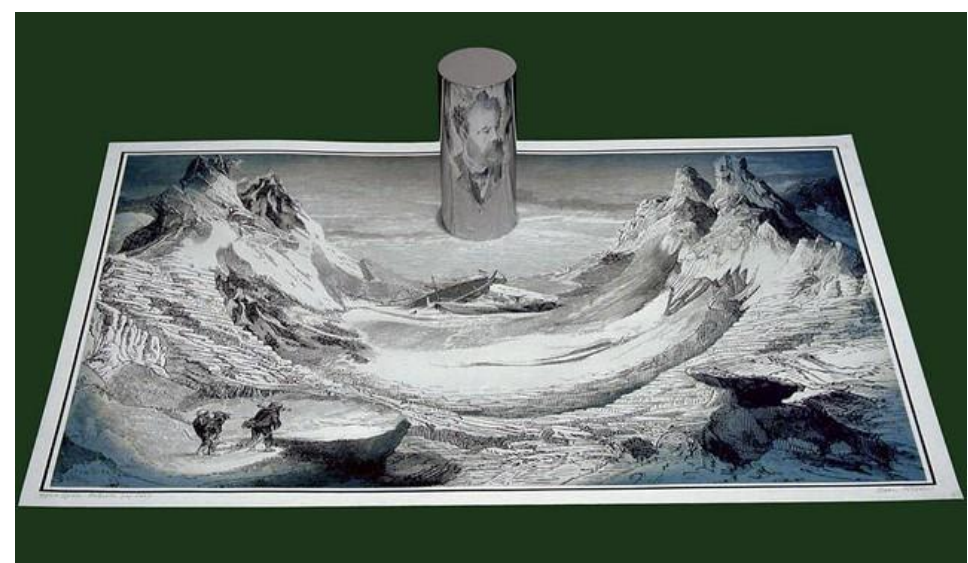

Görsel 6. István Orosz, Mysterious Island/Esrarengiz Ada (Jules Verne'ye Anamorfik Sanat Saygısı), (shorturl.at/pyDMV)

$\mathrm{Bu}$ resmin ortasındaki vadi, silindirik aynadaki yansımasıyla gözlendiğinde, görsel şaşırtıcı bir şekilde bir portreye dönüşür ve sanatçı bununla gördüğünüz her şeyin gördüğü gibi olmadığını anlatırken tek yapıtla iki anlamlı ifadeler sunar. Buradan istenen görüntünün en etkili biçimde elde edilebilmesi için bunlardan herhangi birinin eksik olmamasıdır. 


\subsection{Perspektif (Oblique/Ĕgik/Stereoskopik) Anamorfoz}

İnsan gözü, yaratılış özelliği gereği, her biri farklı görüş alanına hâkim olmakla birlikte, her ikisinin de gördükleri ortak alanlar da mevcuttur. Buna bağlı olarak perspektif anamorfoz yöntemiyle oluşturulan bir görüntü kamera ile izlendiğinde beyin onu üç boyutlu (3B), yani belli bir kütleye ve hacme sahipmiş gibi görür ve böylece, derinlik yanılsaması binöküler olarak algılanır (bunun zıttı monoküler görme şeklidir). Araştırmanın çerçevesi dışına çıkmadan, yapılan araştırmalar sonucunda E. Sertalp'a göre, "İnsanın üç boyutlu görmesini sağlayan şeyin iki gözün görmesiyle ilgili olmadığı asıl nedenin gözün netlik yapma yeteneğidir" (2016: 250).

Üç boyutlu yanılsama etkisiyle yaratılan stereoskopik efekt, Sertalp'ın (2016: 250) “3 boyutlu etki yaratma ve düz satıha derinlik kazandırma(...)" şeklinde tanımladığı, fotoğraf ve sinemada kullanılan "anaglyph" yöntemi için de ilham kaynağ 1 olmuştur. Nitekim R.M. Hayes (1989: 133), 1852 yılında Wilhelm Rollmann tarafından keşfedilen ve 1891 yılında Fransız Louis Ducos du Hauron tarafından geliştirilen "anaglyph" yöntemi, stereoskopik üç boyut yanılsaması sunan sinema ve fotoğraf yöntemlerinde kullanıldığına işaret eder (aktaran: Sertalp, 2016: 255). Oysa temelde aynı ya da benzer bir mantık işleyen bu iki yöntemden ilk keşfedilenin yüzyıllar önce anamorfoz olduğu açıktır.

Perspektif anamorfozu (eğik veya stereoskopik anamorfoz da denebilir), perspektifin bir alt birimi olarak işlev görse bile, doğrusal perspektiften farklı, kendine özgü kuralları olan, hatta doğrusal perspektif ile neredeyse tam tersi işlenen bir perspektif uygulaması şeklinde tarif edilebilir. Erika Gerhold ve Angela Rose'un da belirttiği gibi bu anamorfoz türünde çoğunlukla görüntü doğrusal perspektifin aksine izleyicinin projeksiyonu doğrultusunda uzatılarak elde edilir (2012: 449). Bu nedenle, ilk başta, izleyicide kafa karışıklığına neden olabilir. Zira, doğrusal perspektif mantıklı ve pratik bağlantılar sunarken, anamorfozun etkisi izleyicinin görüntüyü rasyonel hale getirilmeden önce ikileme ve kuşkuya neden olur.

Teknik bakımdan stereoskopik bir anamorfozun izleyicide neden olduğu kafa karışıklığı, başka bir ifadeyle, izleyiciyi iki boyutlu bir görsel üzerinden üç boyut yanılsamasına kandırma yöntemini gösteren projektif bir örnek Göersel 7'de görülebilir.

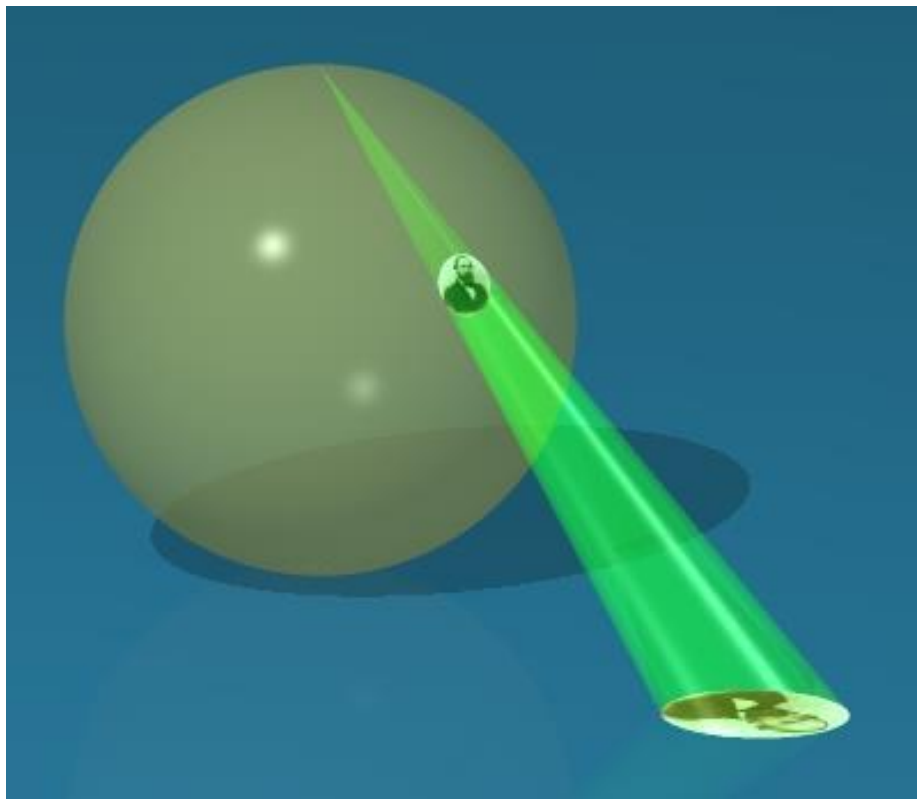

Göersel 7: Stereografik projeksiyon kaynağının bir görseli üç boyutta gösteren bir örnek, (shorturl.at/hlnu2) 
Sahip olduğu gizem veya şaşırtıcı özelliği nedeniyle izleyicinin dikkatini çeken bu tip uygulamaların görüntüleme konusunda bakışın nesne ile bağlaşma yeteneğine işaret eder. Bu ilişkiyi ironik olarak değerlendiren Collins'e (1992: 75) göre bu, kendi vücudunun öznel özerkliğine daldırılan eksantrik gözlemci, izleyicinin alanını işgal etmede ısrar eden sanal bir nesneyi algılama şeklinde yorumlar. Bu, nihayetinde bir veya daha fazla kaybolan noktada birleşen klasik perspektifin tersidir.

Teknik bakımdan bu tip anamorfozlarda sanatçı, doğrusal perspektif kurallarını dönüştürerek; genellikle tersi kurallar uygulayarak izleyiciyi alışılmışın dışına davet eder ve onu bir tür paradoksun içine çeker. $\mathrm{Bu}$, bir görüntüyü başka bir görüntünün yüzeyine aktararak üretilen yeni ve kompleks etkiler oluşturma benzer. Bu karmaşık yapı, bir objeye farklı iki noktadan bakılması sonucunda, objeyi farklı şekilde görmek gibi bir paralaks etkinin gücüyle izleyicide psikolojik bunalıma neden olur. Bunun çağdaş çok sayıda örnekleri olmakla birlikte, klasik bir örnek olması bakımından en başat örneği Hans Holbein'in meşhur Elçiler resminde karşımıza çıkar (Bkz. Görsel 8). Bu resimde tüm nesnelerin bir düzen içerisinde yerleştirilmesine karşın, zeminde halının üzerine açı11, eğik ve biçimsiz bir şekilde yerleştirilen bir kafatası tüm düzeni bozmaktadır. Eğik biçimde resmedilen bu nesneye doğru bir açıdan bakıldığında, resmin geneline yansıyan rahatsız edici görüntünün tümüyle şaşırtıcı bir şekilde ortadan kalkar ve böylece, görsel bozukluk tamamen ortadan kalkar.

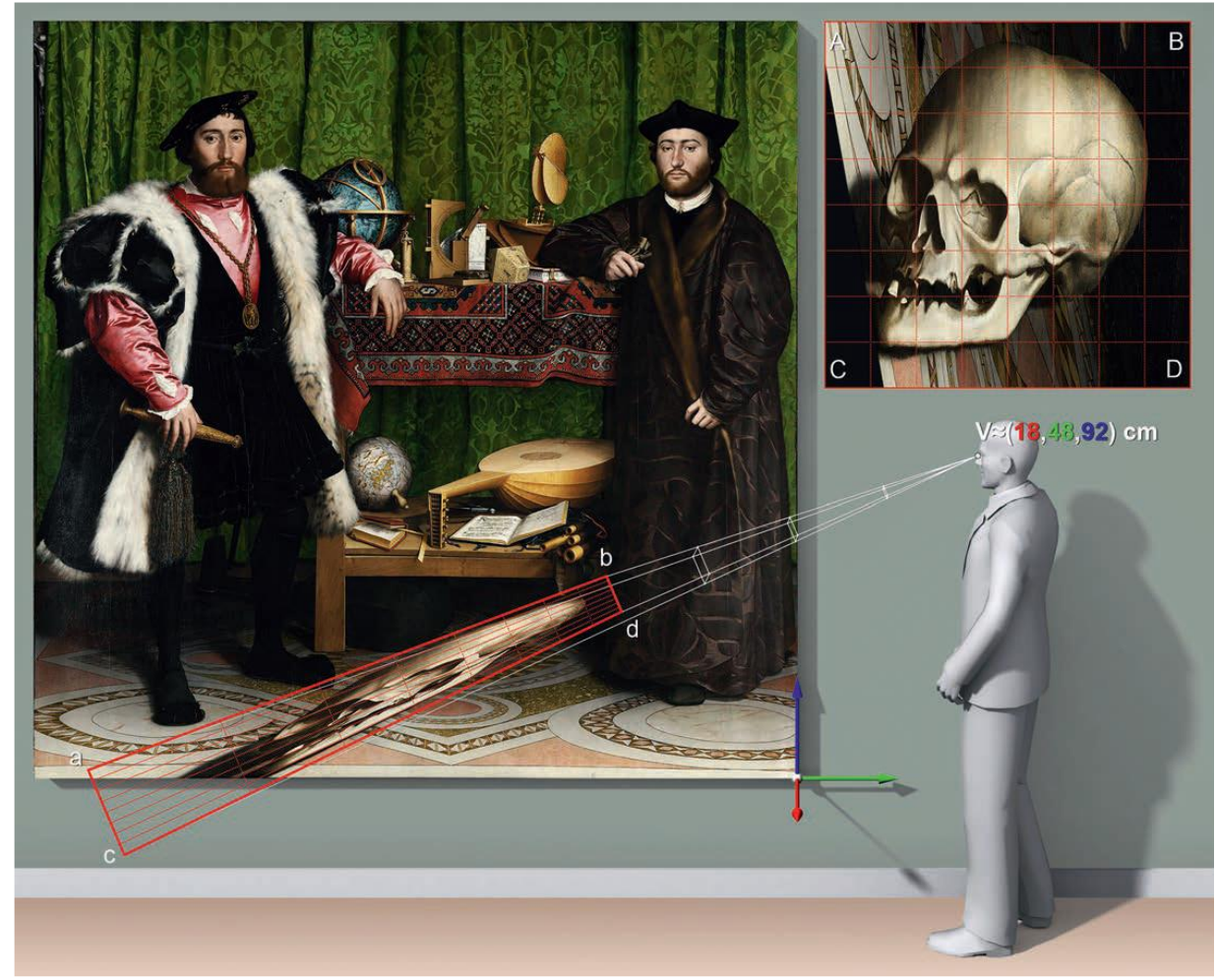

Görsel 8: Hans Holbein The Younger, Elçiler, 1533, 207 cm x 209 cm, yağlıboya ahşap üzerine, National Gallery, Londra (Cabezos, vd., 2014: 151)

Bu resmi mekânsal açıdan değerlendiren Yılmaz (2013: 80), yassılaştırılmış bu anamorfik görüntünün bir kafatası imgesi olup, mekân algısı bakımında çok önemli bir önermenin başlangıcını oluşturduğunu ve imgenin görülmesi için, izleyiciyi zor bir pozisyona soktuğunu belirtir. Bu nedenle resimde imge, mekân ve eserin bulunduğu mekânın ikiliğini vurgulayan karmaşık bir yapıt olduğunu da açıklar. 
Resimde aslında ölümü anlattığı sanılan, bu kafatasının neden tüm düzene aykırı resmedildiği yapılan yorumlar ve okumalar dışında net bir bilgiye ulaşılamamaktadır. Görsele sol taraftan (izleyiciye göre sağ) duvara (tuvale) sıfır noktasına yakın ve belli bir mesafe tablonun uzağından ve belli bir yükseklikten (kafatasını orantılı bir biçimde görebilmek için doğru açı olduğu kabul edilen pozisyondan) bakılınca, ancak o zaman kafatasındaki anormalliklerin tümüyle yok olacak biçimde tasarlandığı fark edilebilir.

\section{Street Art)}

4. Çağdaş Bir Anamorfoz Uygulayıcısı olarak Wenner ve Kaldırım Uygulamaları (3D

Günümüzde üretilen çoğu şeyin "sahte gerçekler" üzerinden tanımlandığı ya da anlam kazandığı; yanılsamanın, kandır(11)manın moda olduğu, hiçbir şeyin gerçeği yansıtmadığı, hareketli (sinema, televizyon vb.), hareketsiz (fotoğraf-makinesi, resim vb.) görsellerin, işitsel (ses, müzik) unsurların, teknolojik (yazılımlar, 3 b yazıcılar vb.) gereçlerin, hatta yapay zeka araştırmalarında bile birçok şeyin boyut değiştirdiği, holografik ve simülatif sunumlarla hemen her gün yazılı ve görsel medya aracılığıyla karşımıza çıkmaktadır. İnsanlar günlük hayatlarındaki bu yeniliklere hızlıca alışmakta ve bu tür aldatma ve yanılsamalara karşı hayranlık duymaktadır.

Böylesi bir atmosferde, yanılsama düzeneği temelli imge ve uygulamalar geniş kitlelere hitap eder bir noktaya gelirken, anamorfik prensiplere dayalı uygulamalar belki de tarih boyunca hiç olmadığ kadar sanat, reklam, tasarım, bilim, teknoloji, tıp, sosyoloji, felsefe ve diğer alanlar tarafından ilgi görür hale gelir. Tuval, fresk ve çukur baskı örneklerinden sonra anamorfik uygulamalar, günümüzde halka açık alanlara; sokaklara, caddelere, kaldırımlara, parklara, dış cephe duvarlarına, şehir meydanlarına ya da kendine özgü hazırlanmış özel alanların yanı sıra; alışveriş merkezlerinde, evlerde, özel şirket ve ofislerde yapılan devasa uygulama örnekleriyle karşılaşmak olağandır. Genelde bu tip çalışmalar uzun süre kalıcı olamayan (geçici) ya da yarı kalıcı materyallerle uygulanan bir tür performans sanatı şeklinde genelleştirilebilir.

Kurt Wenner tarafindan 1984'de icat edilen ve yaklaşık on beş y1l sonra Julian Beever ve diğer bir çok sanatçı tarafından da uygulanan (K. Winner, görüşme, 26 Mart, 2016; Krols, 2010: 61), k1sa sürede dünya genelinde bir fenomene dönüşen "3D Chalk Art", "3D Sidewalk Art", "3D Pavement Art", "3D Street Art", "3D Illusion", "Anamorphic Art", "3D Painting", "Tricky Eye Art" ya da sadece "3D Art" gibi farklı isimlerle adlandırılan bu yeni ifade biçimi tasarım, arazi, dijital, performans, enstalasyon, interaktif ve kavramsal gibi her tür güncel sanat uygulamalarına entegre olmuş, sanatçı için yeni ampirik alanlar sunan bir ifade dilidir.

Günümüz 3B kaldırım uygulamalarıyla tanınan bir diğer önemli sanatçı Julian Beever'ın 3B kaldırım uygulamaları üzerine yazdığı kitapta bu fenomeni: "Çarpıtılmış olarak çizilen, ancak doğru açıdan ve kamera ya da fotoğraf makinesi gibi bir lens kullanılarak bakıldığında, sorunun ortadan kalktığ̣ ve resmin normal şekline dönüştüğü uygulamalar” (2012: 9) şeklinde tanımlar.

NASA'da uzmanlık alanı perspektif olan Wenner, bilim insanlarının teknik çizimlerini ve Dünya dışı nesneleri anlaşılır kılmak için illüstratör olarak yeniden çizmekle görevliydi. Ayrıca, dünya dışındaki sistemlerin yüzey arazilerini ve gelecekteki olası uzay projelerinin imgelerinin tasarlıyordu. Rönesans kaynaklı klasik çizim ve geleneklere karşı sürekli bir hayranlık besleyen sanatçı, 1982 yılında, Roma'da klasik heykel sanatı okumak ve bu alanda uzmanlaşmak üzere NASA'dan ayrılan sanatçı, burada heykel bölümü okurken, kaldırım ve asfalt üzerine resim yapan geleneksel İtalyan madonnari ${ }^{1}$ ressamlarıyla tanışır. Bu alana ilgi duymaya başlayan sanatçı, uzun süre müzelerdeki klasik ve barok dönem usta sanatçıların çalışmalarını derinlemesine gözlemleyip araştırır ve bu tarzda uygulamalar yapar. İtalyan madonnari sanatçıların yöntemini ve kendi

\footnotetext{
${ }^{1}$ Madonnari: İtalyan geleneksel sokak ressamlarına verilen addır ki, bu ressamlar, Bakire Meryem resimlerini sokaklara; yerlere duvarlara tekrar tekrar yaparlardı. İngiltere'de bunlara Screever ve Almanya'da ise Strassenmaler adı verilir. https://en.wikipedia.org/wiki/Street_painting
}

Turkish Studies, 15(2) 
deneyimini sentezleyerek ilk başlarda zemin üzerine tebeşirle iki boyutlu çalışmalar yapan sanatçı çeşitli sorunlarla karşılaşır. Bir şeylerin eksik olduğunu yaptığı uygulamalar esnasında fark eden Wenner, çeşitli gereksinimler üzerine üç boyut yanılsamasını keşfeder (West, 2011).

Görsel algı, psikoloji ve matematikten faydalanan 3B kaldırım sanatçıları, yüzey üzerine resmettiği bir figürü ayaktaymış gibi ya da uçurumdan aşağı düşüyormuş gibi: inişli-çıkışlı kompozisyonlar oluşturmak için bu yeni geometri biçimini kusursuz bir biçimde uygular. Wenner'ın bu prosedürü sanatsal geleneğin yeniden keşfi ya da tam olarak geleneğin güncelle buluşması şeklinde değerlendirilebilir.

Zira Wenner, tasarım ve kompozisyonlarını kaldırımda eğik bir açıdan izleyerek oluşan bozulmayı önleyen özel resimsel geometrik prensipler geliştirmesi sonucunda bu geleneksel yöntemi yeni bir teknik çözümlemeyle yorumlamaktadır. Bu nedenle resimleri, eğik olarak görüntüleme ile ilgili sorunları düzelten matematiksel olarak tutarlı bir çarpıtma ile oluşturmayı başardı. Wenner'ın anamorfik resimlerinin geniş görüş açısı nedeniyle, sabit bir noktaya monte edilmiş bir balıkgözü kamera merceğinden tanımlanabilecek şekilde tasarlanır. Ortaya çıkan görüntü, boyalı yüzeyi ve çevresindeki mekânı tek bir bileşim halinde birleştirir (Foster, 2006: 24).

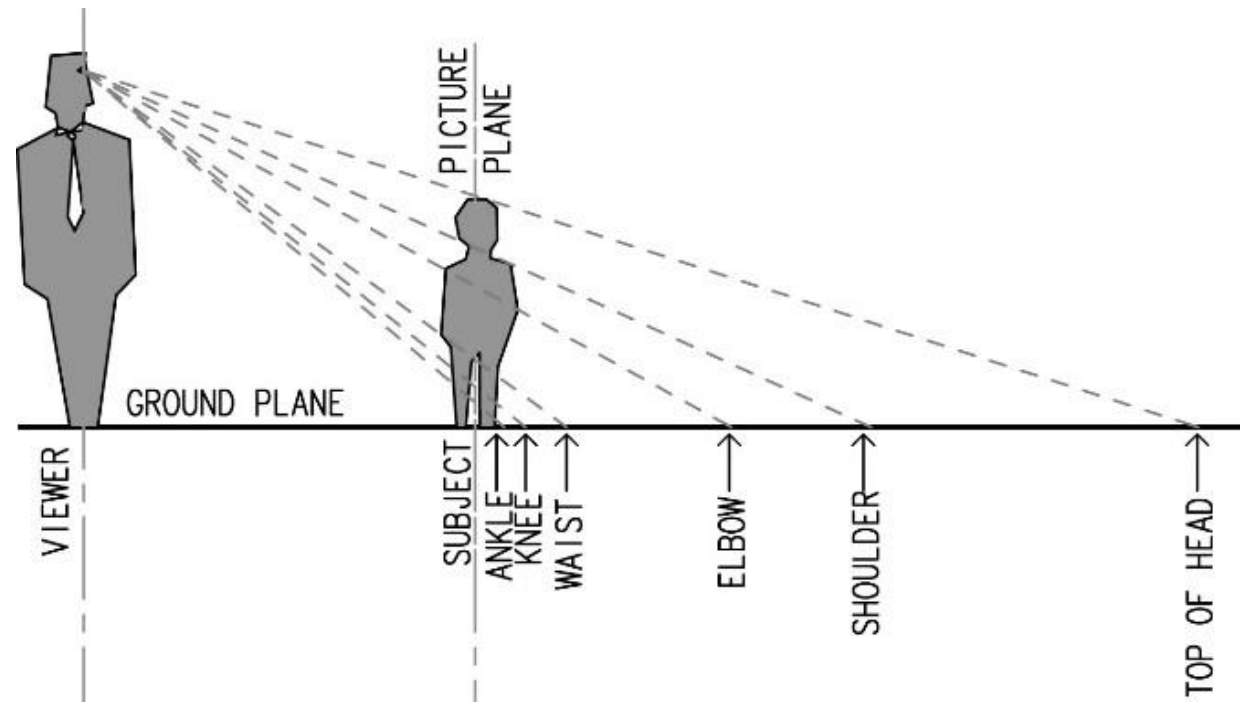

Görsel 9. Wayne Renshaw ve Cheryl Renshaw, Görselin zemin üzerine aktarılma süreci (shorturl.at/jzF67)

Barok kubbe ve tavan resimlerinde kullanılan quadraturist uygulamalara aşağıdan bakıldığında mimari öğeler ile resim iç içe geçerek karmaşık bir izlenim sunar. Böylece mimarinin nerede bittiği ya da boyamanın nerede başladığı anlaşılmaz. Kurt Wenner'ın anamorfik resimleri görsellik bakımından bu prensibe dayandığını şöyle açıklar: "Özellikle izleyiciyi "kuşatan" büyük parçalar üzerinde çalışmaktan zevk alıyorum. Onları resim, heykel ve mimari ile birleştirerek, aralarındaki ayrımı sıklıkla bulanıklaştıran yeni yollarla etkileşim kurmaya zorlarım” (Wenner, 2019). Bu da sanat eseri, izleyici, eserin konumlandırıldığı sosyal çevre ve mekân arasındaki etkileşimin uyumlu bir denge yaratmasına olanak sağlar.

Bireysel deneyimler öznel olsa da kaldırım sanatçısı ile izleyici arasında gerçekleşen samimi diyalog nesnel olması bakımından kaldırım uygulamaları, görsel sanatların daha önce algılanan sinırlarına girme ve günümüz maddi olmayan evrensel kültürünün anlatılarını yeniden düzenleme noktasında önemlidir. Tebeşir, soft pastel vb., çoğunlukla kalıcı olmayan boyalarla oluşturulan bu tür anamorfların kentsel bağlamda konumları, insanların aynı anda hem gerçek hem de yanılsama alanı ile etkileşime girmesine olanak sağlar. Bu uygulamaların anıtsal fotoğraf ve video kayıtlarına izin vermesi bakımından bir tür dokümantasyonun oluşturulması yönüyle de ayrıca önemlidir. 
Wenner'ın uygulamaları bunun en iyi ve güncel örnekleri olarak gösterilebilir. Sanatçının ilk 3B kaldırım uygulaması Dies Irae-Gazap Günü etkili örneklerin ilkidir. Sanatçı daha sonra yaptığı 3B uygulamalarında da izlenebileceği gibi Dies Irae'da da boyalı yüzeyin bulunduğu mekanla etkileşime giren, katılımcılar ve çevre arasında uyumlu bir denge yaratan izlenimler sunar (Bkz. Görsel 10). Bu tip optik temelli görsellerin en karakteristik özelliği, izleyici üzerinde fizyolojik, psikolojik ve düşünsel etkiler yaratarak izleyicinin katılımını sağlamasıdır.

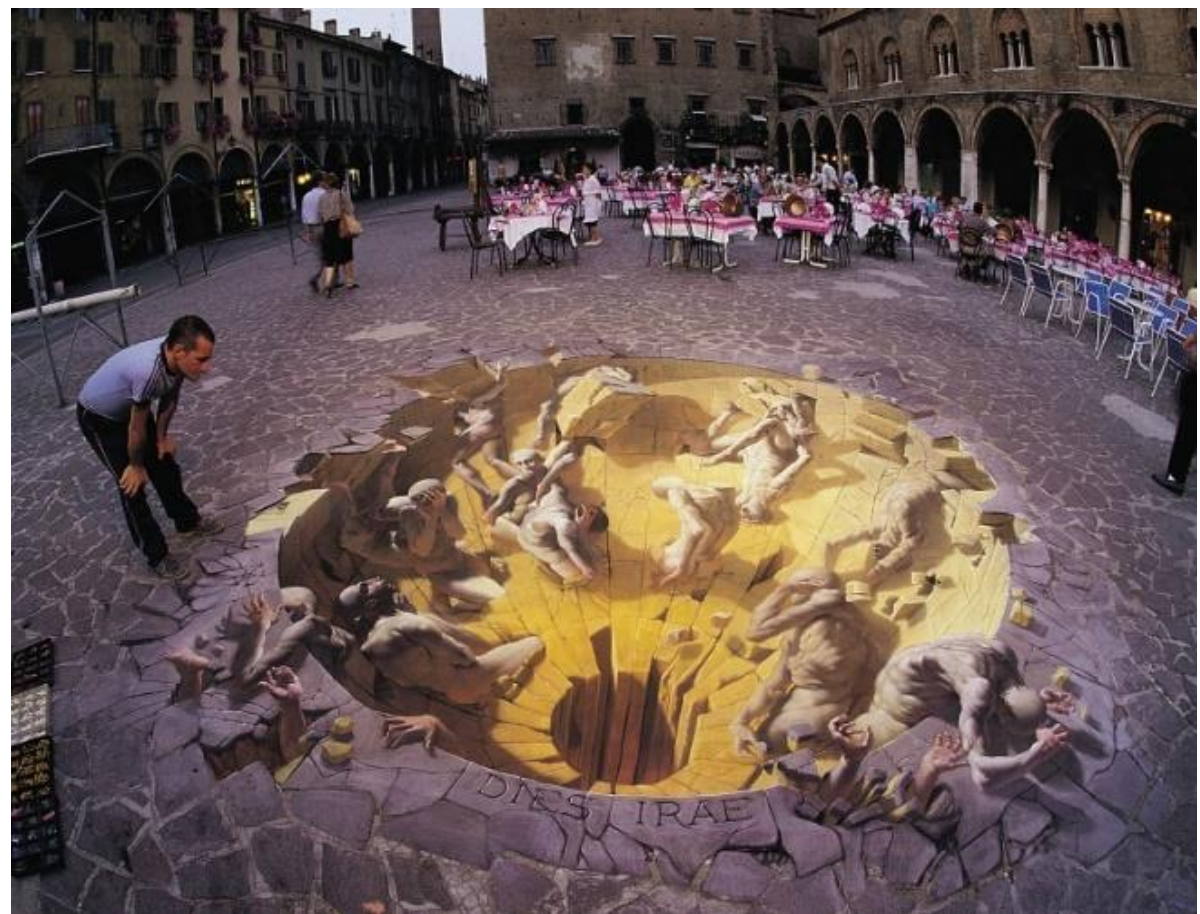

Görsel 10. Kurt Wenner, Dies Irae-Gazp Günü, Mantua/İtalya (https://kurtwenner.com/3d-street-art/)

Kurt, İtalya'da kaldığı süre içerisinde birçok katedral için resimler yaptı. Barok dönemde kiliselerin duvarlarına, tavanların ve kubbelerine yapılan resimleri, yaptığı araştırma, gözlem ve incelemeler sonucunda, uzatılarak resmedilmiş figürlerin normal göründüklerini fark eder ve bu yöntemi kendi çalışmalarına aktarmaya karar verir. Kurt, gelenekten esinlense de yöntem ve tekniği kendine özgüdür. Örneğin, kilise tavanlarındaki resimlerin görüş açıları çok genişken, onun çalışmalarında ise, resme belirlenen bir tek özel açıdan bakılınca deforme edilmemiş hali görülebilir olduğunu belirten Kurt, icat ettiği ya da geliștirdiği bu yeni yöntemin Barok uygulamalarından ve diğer 3B uygulamaları yapan sanatçılardan ne kadar farklı ve yeni bir yöntem kullandığını şu cümlelerle açıklar;

Ben kompozisyonlarımdaki üç boyutu belgelemek için, eğrisel bir balıkgözü lens kullanmaya başladım. Benim geliştirdiğim perspektif 17 . yüzyıl resimlerindekinden farklıydı ve ben onu yayınlamadım. Benim Perspektifim, insan gözünden dışa doğru bir iz düşüme sahip doğrusal perspektifin mantıklı kullanımını birleştirir. Üç Boyutlu Kaldırım Resimlerini taklit eden diğer sanatçılar, "quadratura" "gönyeleme" adında, daha basit hesaplar içeren geometriyi kullanırlar. Onlar benim geometrimin eşsiz olduğunu anlamiyorlar (aktaran: West, 2011).

Sokak sanatçıları önceleri tebeşir, talaş, renkli cam, kuş tohumu, kum, kuş gübresi hatta çiçekle bile, geçici; sadece festival süresince kalabilen malzemeler kullanırlardı. Wenner'ın ise ilk başlarda soft (kuru) pastel kullanmakla birlikte, çoğunlukla kendisinin özel olarak ürettiği bir tür tebeşir kullanılmayı tercih eder. Pastel boyanın çok pahalı olması ve kaldırım, asfalt gibi zeminler üzerine istediği sonucu alamaması sonucunda kendi tebeşirini üretir (Wenner, 2011: 152-154). 
Sanatçının kendi ürettiği malzemelerle büyük bir alana yaptığı önemli uygulamalarından biri Giant-Dev adlı çalışmasıdır (Bkz. Görsel 11). İzleyicilerle kıyaslandığında, resimde yüzeyin yarılarak içerisine yerleştirilen bu büyük insan figürünün boyutu hakkında bize yorum yapma olanağı verebilir. Kurt'un çoğu çalışmasında olduğu gibi Giant-Dev'i de antik dönemin ve klasik dönemin mitolik bir yansıması olarak karşımıza çıkar. Sadece sanatçının belirlediği bir nokta ve belirlediği bir açıdan bakıldığı zaman görüntü deformasyondan sıyrılıp üç boyut yanılsama özelliğine kavuşabilir. Bu özel noktanın dışındaki diğer yerlerden izlendiğinde görüntünün bozulması Wenner'ın çabaları neticesinde geliştirilmiş bu ifade biçiminin karakteristik özelliğine işaret eder.

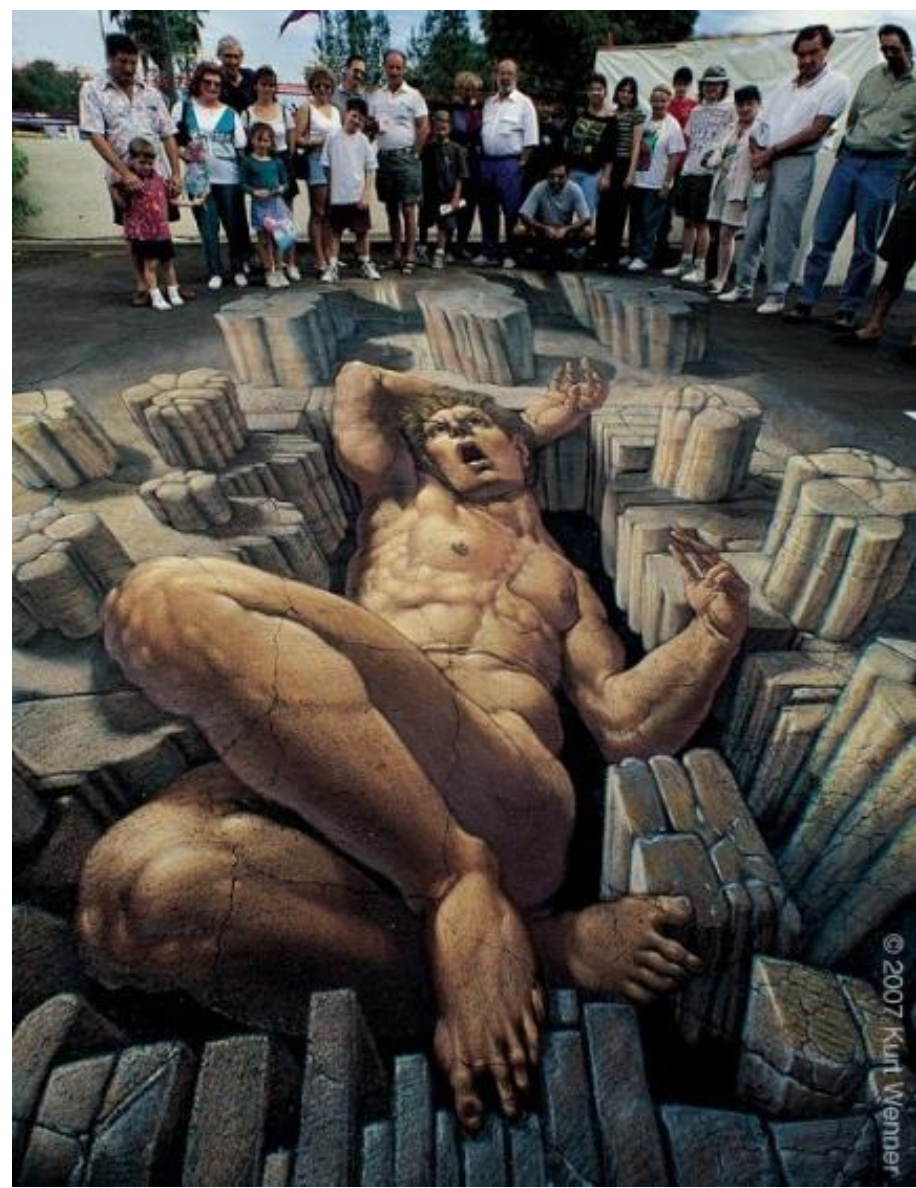

Görsel 11. Kurt Wenner, Giant-Dev, 2007, Scottsdale Arts Festiva, Arizona (https://kurtwenner.com)

3B Sokak Uygulamaları (3D Street Art), güzel sanatlardaki küçük örneklerden büyük kentsel alanları işgal eden resimlere kadar farklı boyutlarda tasarlanabilir. Anamorfozlar karmaşı yüzeylere çizilebilir veya birkaç farklı düzlem üzerine yayılabilir. Kentsel alanda, anamorfozlar çoğunlukla yatay düzleme çekilir, çünkü kentsel alanda sokaklar ve meydanlar gibi geniş alanlar, zemin seviyesinde duran bir gözlemci için yanılsamalı bir etki yaratmak için idealdir (Stojakovic ve Tepavcevic, 2016: 761, 762).

Kurt Wenner'ın uygulamaları ve bu ifade biçimini tanıtma çabaları, farklı ülkelerde verdiği seminerler, katıldığı workshoplar, yarışmalar, festivaller, verdiği eğitimler ve çalışmalarının internet üzerinden paylaşılması ve sosyal medya üzerinden çok sayıda destekçi bulması, bu sanat türünün kısa sürede dünyanın her tarafina yayılmasına yol açar. 1985 yılında Wenner İtalya'da üç yıl üst üste katıldı $\breve{g}_{1}$ Grazie festivalinde Altın Madalya kazanan ilk Amerikalı olarak kayıtlara geçerken, ayrıca "sokak sanatı ustası" unvanına da sahip olur (VanLear, 2014: 26). 
Wenner' in etkisi ve girişimleriyle son yıllarda Grazie di Curtatone (Mantova), Lake Worth Street Painting Festival (Florida), Sarasota Chalk Festıval (Venedik), I Madonnari festival (Santa Barbara), Lake Worth Street Painting Festival (Florida) bu alanda düzenlenen en büyük festivallerden bazılarıdır.

1987 yılında çekilen ve Wenner'ın Avrupa'daki eserlerini konu alan Tebeşirle Yaratılan Başyapıtlar başlıklı National Geographic belgeseli, New York Film Festivali'nin güzel sanatlar kategorisinde birincilik ödülü alır. Fransa'dan Tayvan'a, Hong Kong'dan Güney Afrika'ya 24 farklı ülkede farklı çalışmalara yapan Wenner, birçok farklı kurum, okul, müze ve topluluk için özellikle "İtalyan sanatında biçim ve yanılsama", "perspektif ve yanılsama", "temel çizim teknikleri", "renk ve çizim teknikleri" konularında atölyeler düzenlemesiyle bu sanatın tanıtılmasına hızlandırdı. Mimarlık eğitimi almamış olmasına rağmen sanatçı, yağlı boya tablo, fresk, mimari ve heykel, iç mimarlık ve tasarım alanlarında da eserler vermektedir (Biçer, 2011).

Aynı zamanda özgün mimari tasarımlar, resimler, heykeller, dekorasyonlar gibi birçok alanda üretmekle birlikte Wenner, en çok "Üç Boyutlu Kaldırım Sanatı" mucidi ve en iyi uygulayıcıs1 olarak bilinmektedir. Sanatçının en çok bilinen 3B çalışmalarından bazıları; Dies Irae (İtalya), The Flying Carpet (İtalya), Incident at Waterloo (İngiltere), Einstein is Impressed (Japoya), The Three Magi (Meksika), Runaway Stagecoach (Türkiye), The Giant (Arizona), Beowulf (ABD), Woman Driver (Bahreyn), Honda Formula I (Endonezya), Classic Lines (ABD), Spiderman (Japonya), Gears of War (ABD), Crash Site (ABD), The Belgian Underground (Belçika), The Big Salad, Hell (İngiltere), A Millionaire's Life (Singapur) ve Last Judgment olarak sayılabilir.

\section{Sonuç}

Anamorfoz, perspektifin küçük bir bölümünü oluşturmakla birlikte, sanatçılar tarafından çevremizdeki dünyayı temsil etmek için, temelde, geometri ve algı psikolojisini etkin bir biçimde kullanarak sanat dünyasına sunar. Sadece ayrıntılı bir planlama, hesaplama ve perspektifin gerektirdiğinden çok daha fazla hazırlık yapılarak gerçekleştirilebilir. Aksi taktirde istenen sonuç elde edilemez ve sanatçıda hayal kırıklığına neden olabilir. Kamusal alanda böyle bir performans gerçekleştirilmesi durumunda ise sanatçının izleyici (gözlemci, ziyaretçi) karşısında alaylı bir pozisyona düşmemesi için mutlaka tasarımı ve tüm hesaplamaları çok dikkatli bir biçimde yapması gerekir.

Bilinen en eski örneği Davinci tarafından kaydedilen anamorfik perspektif (Kodeks), Rönesans sanatçıları dışında, özellikle de, 16. - 19. yüzyıl sanatçıları üzerinde önemli etkilere sahip olmuştur. Anamorfik perspektif 19. yüzyılın son çeyreğine kadar çeşitli değişikliklerle süre gelse de 20. yüzyılın son çeyreğine yakın bireysel ve nadir uygulamalar haricinde çok fazla tercih edilmemiş, hatta kendisinden uzak durulmuştur. 1960'lardan sonra bu konuda eğilimler canlanmaya başlar, 60/70'lerde S. Dali'nin katoptrik anamorfozları, Hollandalı Kavramsal sanatçı Jan Dibbets'nin tellerden üç boyutlu trapez biçimindeki şekilleri ya da çim alanlarının kazılması biçimindeki uygulamaları, Felice Varini'nin iç ve dış mekanları saran geometrik şekilleri ya da István Orosz'un katatropları, nihayetinde 80'lerin ikinci yarısına doğru Kurt Wenner'ın matematik/geometri üzerine yaptığı araştırmalarıyla çağdaş "anamorfoz"a yeni bir boyut kazandırarak konuya olan ilginin hızlıca aratmasına neden olur. Böylelikle sanat dünyası başta olmak üzere anamorfoz birçok alanda tercih edilir noktaya gelir.

Kendi içerisinde gizlilik ve aykırılık içeren, gerçeği simülatif bir imge ile perdeleme yeteneğine sahip manipülatif eylemlere ve deneyselliğe olanak sağlayan anamorfoz, izleyicinin algısı üzerine hâkim bir etki oluşturabilme gücündedir. Bu teknikle sanatçılara yaratıcılıklarını ifade etmenin iki yolunu sunar: Bunlardan biri perspektif (eğik) anamorfoz diğeri ise ayna (katoptik) anamorfoz olarak adlandırılır. Bunların her biri farklı dönemlerde etkili birer ifade biçimine dönüşse 
de günümüzde, katoptrik olana oranla perspektif anamorfoz (günümüzde buna stereoskopik anamorfoz da denir) birçok sanatçı tarafından tercih edilir.

Önemli bir başka konu ise, “anamorfoz" ve "tropl l'oeil”nün birçok araştırmada aynı şeylermiş gibi sunulmasının yarattı̆̆ı karışıklıktır ya da ortak noktalarının öne çıkarılması nedeniyle sinırları arasında meydana gelen bulanıklıktır. Perspektif yapısı her iki durumda da sadece belirli bir bakış açısından doğru görülen bir görüntü oluşturmak için kullanılsa da Perspektif anamorfoz, genellikle alışılmadık özel bir bakış açısından doğru olarak görülür ve genellikle neredeyse tanınmayacak kadar çarpıtılmıș olması yönüyle trompe l'oeil'den ayrılır. Fakat "trompe l'oeil"de, sanatçı genellikle tüm sahneyi mekansal olarak sunma niyetinde oluğu için, burada herhangi bir parçanın bozulması, çarpıtılması istenmeyen bir durumdur.

Y1llarca Rönesans ve Barok dönem tavan ve duvar uygulamalarını -bu iki dönem sanat anlayışına duyduğu hayranlıktan ötürü- yakından inceleyen Wenner, 1984 yılında geleneksel anamorfozu çeşitli yönlerden geliştirerek bu tekniği yine İtalya kökenli sokak sanatıyla buluşturarak yeni bir dil meydana getirir. Wenner'ın bu yöntemi sokak sanatında devrim niteliğinde kabul edilir. Aslında sadece sanat değil aynı zamanda tasarım, mimarlık, teknolojik gereçler; özellikle de televizyon, projeksiyon cihazları, bilgisayar destekli yazılım ve donanımlar, 3D / 3B yazıc1 teknolojisi, stereoskopik gereçler (sinema), hatta Emes hastalığı testi gibi farklı alan ve branşlar üzerinde önemli etkilere sahip olduğu görülür. Ayrıca günümüzde, yüzey anamorfozu (3B Kaldırım Uygulamaları) Kurt Wenner dışında Julian Beever, Manfred Stader, Leon Keer, Edgar Muller, Eduardo Relero ve François Abélanet gibi birçok sanatçı tarafından sokaklar ve duvarlar bir tuval gibi kullanılarak sürdürülür.

\section{Kaynakça}

Baltrusaitis, J. (1977). Anamorphic Art. (Translated by WJ Strachan). Cambridge, England: Chadwyck-Healey.

Baltrušaitis, J. (1995). Aberrations: Les Perspectives Dépravées-1. Paris: Flammarion.

Beever, J. (2010). Pavement Chalk Artist: The Three-Dimensional Drawings of Julian Beever. (2nd Edition), United States: Firely Books.

Belting, H. (2017). Floransa ve Bağdat: Doğu'da ve Batı'da Bakışın Tarihi. (Çev. Z. A. Yılmazer). İstanbul: Koç Üniversitesi Yayınları.

Bernal, P.C., Vivó, J.C., \& Sanz, F.S. (2014). Anamorphosis, Its History and Evolution. EGA (Expresión Gráfica Arquitectónica), 19(23), 148-161.

Biçer, S. (2011). Sanata Bir İyilik Yap, Sokağa At! "Kurt Wenner Vestel 3D Led TV İçin Türkiye'de". Arkitera E-Bültenleri. http://v3.arkitera.com/arsgratiaartis.php?action=displayNewsItem\&ID=64276.

Boyle, J. E. (2010). Anamorphosis in Early Modern Literature: Mediation and Affect. United States: Ashgate Publishing, Ltd.

Cabezas-Jiménez, M.M. (2007). Imaginario Urbano: Expresión Gráficoplástica En El Espacio Público. Tesis Doctoral, Universidad De Granada Facultad De Bellas Artes "Alonso Cano" Departamento De Dibujo, España.

Caffio, G. (2018, May). "Anamorphic Perspective and Architectural Space. Two Works by Felice Varini and Georges Rousse". (Ed. Carlos, L.M.), Graphic Imprints The Influence of Representation and Ideation Tools in Architecture. In Congreso Internacional de Expresión Gráfica Arquitectónica, Cham/ Switzerland: Springer, pp. 1293-1302. 
Colchero, J.A.S. (2018). Arte, Anamorfosis y Percepción Espacial: La Realidad Del Observador. AusArt, 6 (1), 249-259.

Collins, D.L. (1992). Anamorphosis And The Eccentric Observer: Inverted Perspective and Construction of The Gaze. Leonardo, 25(1), 73-82.

Coxeter, H.S.M. (1974). Projective Geometry. (2nd Edition), Toronto: Univerity of Toronto Press.

Dahan-Dalmedico, A \& Pfeiffer, J. (1984). Une Histoire Des Mathématiques: Routes Et Dédales. Paris: Éditions du Seuil.

Eaton, T. (2011). 3D Art Book. New York: Prestel Art.

Edgerton, S.Y. (1979). The Art Bulletin. JSTOR, 61(1), 131-134.

Foster, C. (2006). Anamorphic Art. Mathematics Teaching Incorporating Micromath, 199, 24-25.

García, H.M. (2016). "La Anamorfosıs En La Urbe Y El Arte Contemporáneo”. (Ed. Sánchez, M. Á.A.), Intervenciones Efimeras En El Espacio. Ciudad Juárez Publicaciones universitarias, México, pp. 27-45, http://www2.uacj.mx/publicaciones/ Erişim Tarihi: 11.01.20120

García-Salgado, T. (2001). “Anamorphic Perspective and Illusory Architectur”. (İspanyolca'dan İngilizce'ye Çev. N. Siders), 1-18, http://www.perspectivegeometry.com/ Erişim Tarihi: 20.06.2019

Gerhold, E. \& Rose, A. (2012, March 29-31). Anamorphic Art with A Tilted Cylinder. 2012 Proceedings of The National Conference on Undergraduate Research (NCUR), Weber State University, Ogden Utah / United State, pp. 449-456.

Hansford, D. \& Collins, D. (2007). Anamorphic 3D Geometry. Computing, 79 (2-4), 211-223.

Hayes, R.M. (1989). A History and Filmography of Stereoscopic Cinema, North Carolina: Perspecta Systems Ltd.

Internet: shorturl.at/kpwAT, Erişim Tarihi: 03.01.2020.

Kocalan, M. ve Türkdoğan, T. (2018). Çağdaş Sanatta Bir Yanılsama Tekniği: 'Anamorfoz' ve Felice Varini. Journal of History Culture and Art Research, 7(1), 527-541.

Krols, B. (2011). 3D Street Art. Belguim: Tectum Publishers.

Lambert, F. (2014). Images in Distortions: From Anamorphosis to Conformal Mappings. International Journal of the Image, 4(4), 63-70.

Laming, M., \& Rogi, O. H. (2016). Konsep Ilusi Anamorfosis Dalam Arsitektur. Media Matrasain, 13(1), 24-37.

Lazzaro, D. P. \& Murra, D. (2013b). Figurative Art, Perception and Hidden İmages İn İnverse Perspective. ENEA (Technical Unit for Radiation Application Development), 1(2). 42-51.

Lazzaro, D.P., \& Murra, D. (2013a). L'anamorfosi Tra Arte, Percezione Visiva e "Prospettive Bizzarre”. ENEA (Technical Unit for Radiation Application Development), 1-27.

Lazzaro, P.D., Murra, D., \& Vitelli, P. (2019). The İnterdisciplinary Nature of Anamorphic İmages in A Journey Through Art, History and Geometry. Journal of Mathematics and The Arts, 13(4), 353-368.

Leeman, F., \& Schuyt, M. (1976). Hidden Images: Games of Perception, Anamorphic Art, Illusion: From The Renaissance to The Present. New York: Harry N. Abrams. 
Melnikova, E. I. (2011 January). Anamorphic Art. In VII All-Russian Conference: Youth and Science, Krasnoyarsk/ Russia: Siberian Federal University, pp. 22-25, http://www.elib.krasu.ru/handle/2311/4893 Erişim Tarihi: 15.02.2019

Murra, D., \& Di Lazzaro, P. (2014). Analytical Treatment And Experiments Of The Virtual İmage Of Cone Mirrors. Applied Physics B, 117(1), 145-150.

Paola, F.D., Pedone, P., Inzerillo, L., \& Santagati, C. (2015). Anamorphic Projection: Analogical / Digital Algorithms. Nexus Network Journal, 17(1), 253-285.

Pizlo, Z. (2008). 3D Shape: Its Unique Place in Visual Perception. Cambridge, Massachusetts: The MIT Press.

Ravnik, R., Batagelj, B., Kverh, B., \& Solina, F. (2014). Dynamic Anamorphosis As A Special, Computer-Generated User İnterface. Interacting With Computers, 26(1), 46-62).

Seckel, A. (2004). Masters of Deception: Escher, Dali \& The Artists of Optical Illusion. New York: Sterling Publishing Company.

Sertalp, E. (2016). Stereoscopic Fotoğrafın Üretim Süreci ve Günümüzdeki Uygulamasına Bir Örnek: “Ayağıma Gelen Tarih” Projesi. Moment Dergi, 3(1), 248-264.

Sözen, M. ve Tanyeli, U. (2010). Sanat Kavram ve Terimleri Sözlüğü. İstanbul: Remzi Kitapevi.

Spiliotis, A. (2008). Illusionism in Architecture. Doctoral Thesis, Manchester Metropolitan University, Dissertation for the Degree of Bachelor of Architecture, Manchester, United Kingdom.

Stillwell, J. (2010). Mathematics and Its History. New York: Springer.

Stojakovic, V., \& Tepavcevic, B. (2016). Distortion Minimization: A Framework For The Design of Plane Geometric Anamorphosis. Nexus Network Journal, 18(3), 759-777.

VanLear, R. (2014 September/October). I Madonnari: The Museum's Chalk Festival Celebrates 25 Years Of Carrying on A Centuries-Old Tradition. Cleveland Art: The Cleveland Museum of Art Members Magazine, 54(5), 26-28.

Veltman, K. H. (1986). Perspective, Anamorphosis and Vision. Marburger Jahrbuch Für, 21, 93117.

Wade, N. J., \& Hughes, P. (1999). Fooling The Eyes: Trompe L'oeil And Reverse Perspective. Perception, 28(9), 1115-1119.

Wenner, K. (2011). Asphalt Renaissance: The Pavement Art and 3-D Illusions of Kurt Wenner. New York: Sterling Signature.

Wenner, K. (2019). “On Story, Allegory, and History”, https://kurtwenner.com/about/ Erişim Tarihi: 15.02.2019.

West, J. Z. (2011). The Incredible 3D Street Paintings Of Kurt Wenner. Business Insider. http://kurtwenner.com/index.htm, Erişim Tarihi: 15.04.2016.

Yılmaz, B. (2013). Mekân Algısının "Elçiler” Konulu Resim ve Minyatür Örnekleri Üzerinden Karşılaştırması. Kalemişi Geleneksel Türk Sanatları Dergisi, 1(2). 73-81. 